\title{
The mass balance of McCall Glacier, Brooks Range, Alaska, U.S.A.; its regional relevance and implications for climate change in the Arctic
}

\author{
B.T. Rabus and K. A. Echelmeyer \\ Geophysical Institute, University of Alaska - Fairbanks, Fairbanks, Alaska 99775-7230, U.S.A.
}

\begin{abstract}
McCall Glacier has the only long-term mass-balance record in Arctic Alaska. Average annual balances over the periods 1958- 72 and $1972-93$ were -15 and $-33 \mathrm{~cm}$, respectively; recent annual balances (1993-96) are about $-60 \mathrm{~cm}$, and the massbalance gradient has increased. For an Arctic glacier, with its low mass-exchange rate, this marks a significant negative trend.

Recently acquired elevation profiles of McCall Glacier and ten other glaciers within a $30 \mathrm{~km}$ radius were compared with topographic maps made in 1956 or 1973 . Most of these glaciers had average annual mass balances between -25 and $-33 \mathrm{~cm}$, while McCall Glacier averaged $-28 \mathrm{~cm}$ for 1956-93, indicating that it is representative of the region. In contrast, changes in terminus position for the different glaciers vary markedly. Thus, mass-balance trends in this region cannot be estimated from fractional length changes at time-scales of a few decades.

We developed a simple degree-day/accumulation mass-balance model for McCall Glacier. The model was tested using precipitation and radiosonde temperatures from weather stations at Inuvik, Canada, and Barrow, Kaktovik and Fairbanks, Alaska, and was calibrated with the measured balances. The Inuvik data reproduce all measured mass balances of McCall Glacier well and also reproduce the long-term trend towards more negative balances. Data from the other stations do not produce satisfactory model results. We speculate that the Arctic Front, oriented east-west in this region, causes the differences in model results.
\end{abstract}

\section{INTRODUCTION}

The Arctic appears to play a crucial role during changes in global climate, both recent and past (e.g. Alley, 1995). General circulation models indicate that increased greenhousegas concentration in the atmosphere may lead to climate warming, and that this warming may be most pronounced in the Arctic (e.g. Houghton and others, 1996). Close monitoring of the Arctic climate is essential to test these predictions.

There are few weather stations in the Arctic, and the climatic interpretation of their records is hampered by large inter-annual variability, short record lengths, heat-island effects and unknown spatial representivity (e.g. Kelly and others, 1982; Bowling, 1991). A complementary approach to detect potential changes in the Arctic climate is to study corresponding changes in natural settings, such as on glaciers (e.g. Cogley and others, 1995, 1996; Dowdeswell, 1995) or in permafrost (Lachenbruch, 1994; Osterkamp and Romanovsky, 1996). The remoteness of glaciers and the cumulative nature in which changes of their mass balance are displayed by their volume and length make them sensitive indicators of climate change. On the other hand, the climatological interpretation of short-term changes of individual glaciers can be difficult, because errors in massbalance measurements can obscure existing trends and because it is not known a priori how representative a particular glacier is within a geographic region. Changes in glacier length are also complicated by glacier flow and there is a poorly understood time lag between changes in mass balance and terminus response (Jóhannesson and others, 1989; Schwitter and Raymond, 1993; Echelmeyer and others, 1996).

In this paper we present annual and long-term massbalance data from McCall Glacier, Alaska. This glacier is located in the northernmost glacierized region of the United States and its mass balance is directly influenced by climate change in this Arctic region. Short-term comparative studies on neighboring glaciers indicate that McCall Glacier is regionally representative. Furthermore, the successful modeling of its mass-balance record, using meteorological parameters from distant weather stations, implies a larger-scale representivity of this glacier's mass balance.

\section{BACKGROUND ON MCGALL GLACIER}

McCall Glacier is located in the Romanzof Mountains at $69^{\circ} 17^{\prime} \mathrm{N}, 143^{\circ} 50^{\prime} \mathrm{W}$, close to the northern front of the northeastern Brooks Range (Fig. l). The glacier is about $8 \mathrm{~km}$ long and has an area of $7.4 \mathrm{~km}^{2}$. Ice originates in three cirques, from east to west, Upper, Middle and Lower, and flows from an elevation of more than $2700 \mathrm{~m}$ to the present terminus at $1350 \mathrm{~m}$ with a mean slope of $8^{\circ}$ (Fig. 2). Precipitation sources for the glaciers in this region are the Bering Sea, about $700 \mathrm{~km}$ to the west, and the Arctic Ocean, about $100 \mathrm{~km}$ to the north. Seasonal mass exchange on McCall Glacier is 


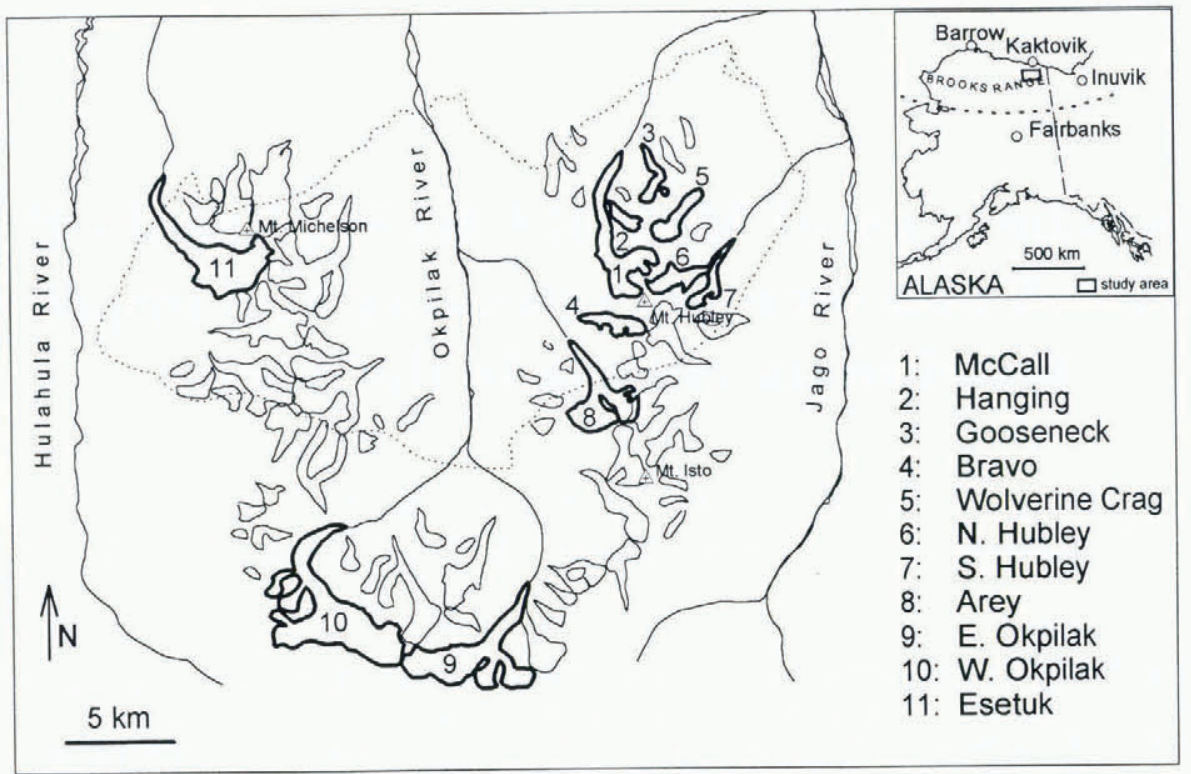

Fig. 1. Existing glaciers between Hulahula and fago Rivers, northeast Brooks Range. Numbers indicate glaciers that were surveyed between 1993 and 1995. The outline of the Okpilak Batholith, a large granitic intrusion, is shown as a dotted line.

quite small: the current winter and summer balances are around 20 and $-60 \mathrm{~cm}$, respectively. Annual precipitation is about $0.5 \mathrm{~m}$ (Wendler and others 1974), more than half of which falls as snow. Trabant and Benson (1986) showed that superimposed ice formation and internal accumulation are significant on the glacier, with the latter contributing more than $40 \%$ of the annual net accumulation. Because of patterns in mountain shading and wind deposition, the equilibrium-line altitude (ELA) is not well-defined; instead it spans an elevation range of $350 \mathrm{~m}$ in an average year (Wendler and Ishikawa, 1974; Trabant and Benson, 1986). The mean annual air temperature is about $-12^{\circ} \mathrm{C}$ at $1700 \mathrm{~m}$ elevation. The near-surface and basal ice temperatures in the accumulation area are between $-1^{\circ}$ and $-1.5^{\circ} \mathrm{C}$ (Orvig and Mason, 1963). In the ablation area, surface-ice temperatures are less than $-10^{\circ} \mathrm{C}$, while the basal ice is temperate, at least near the center line (Trabant and others, 1975).

Previous studies of the surface geometry and the mass and energy balance of McCall Glacier were made during the International Geophysical Year (IGY) in 1957-58 (e.g. Sater, 1959) and during the period 1969-75 (e.g. Wendler and others, 1972, 1974). Our continuing investigations began in 1993 (Rabus and others, 1995) with measurements of surface and bed geometry, mass balance, meteorological variables, ice temperature and ice velocity (Rabus and Echelmeyer, 1997).

\section{DEFINITIONS}

It is important to set forth several definitions of the massbalance terms used in this study. We follow those of Ostrem and Brugman (1991), with some changes in reference to Arctic glaciers.

The mass balance of a glacier can be measured using either glaciological, topographical or hydrological methods. The glaciological method involves measurements of local mass balance using poles and snow density in pits. These data are used to calculate the balance for a given hydrological year, either beginning and ending at a specified date (fixeddate system) or from one summer surface to the next (stratigraphic system). The topographical method compares two sur- faces, defined by surveying the glacier (by photogrammetry or other methods) at two different times. To convert the calculated volume change to mass balance, one must assume a bulk density for the (unknown) proportions of ice, firn and snow that are lost or gained. In contrast to the glaciological method, in which systematic errors accumulate, the topographic method becomes more accurate when evaluated over a longer time span (Krimmel, 1989). Both glaciological and topographical methods have been used on McCall Glacier (Trabant and Benson, 1986; Rabus and others, 1995). The hydrological method determines mass balance from precipitation and the discharge of an outlet stream. The geometry of the drainage basin and aufeis formation makes this method unfavorable for McCall Glacier (Wendler and others, 1972).

Two additional sources of accumulation, internal accumulation and superimposed ice, complicate mass-balance measurements on Arctic glaciers with their cold surface temperatures (e.g. Wakahama and others, 1976; Trabant and Mayo, 1985; Trabant and Benson, 1986). Internal accumulation occurs by the refreezing of surface water that percolates below the previous summer surface into the firn and macroscopic features such as crevasses. Superimposed ice forms near the equilibrium line by refreezing of water on top of the last summer surface. Both contributions to the mass balance are considered by using the topographical method over sufficiently long time periods. In contrast, the glaciological method, which usually determines the surface balance above the last summer surface, includes only superimposed ice. Internal accumulation must be estimated independently. We define the net balance as the sum of the surface balance and this internal accumulation.

Various methods can be used to calculate the balance for the entire glacier given the local pole balances. In the balance vs elevation method, a low-order polynomial is fitted to the local balances vs elevation. The net balance is then obtained as a sum of interpolated local balances in successive elevation bands, weighted according to the area-elevation distribution of the glacier. In a different approach, a contour map of mass balance is constructed using two-dimensional interpolation of the local balances. Then numerical integration of the balance over the glacier surface gives the net balance. 

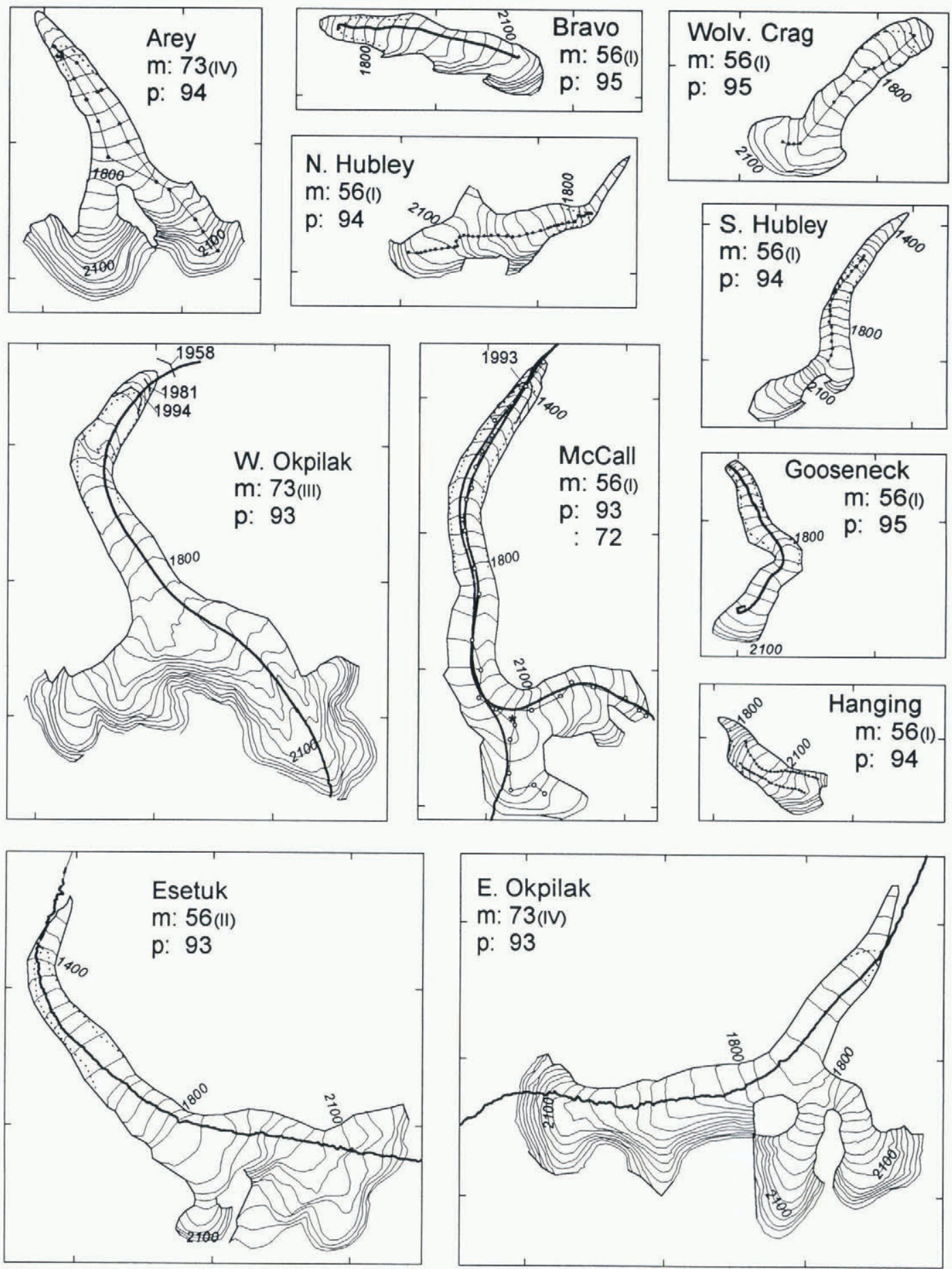

Fig. 2. Maps of surveyed glaciers, with elevation contour interval of $100 \mathrm{ft}(\approx 30.5 \mathrm{~m})$. Elevation labels in meters are added where $100 \mathrm{ft}$ contours coincide with $100 \mathrm{~m}$ contours to better than $\pm .5 \mathrm{~m}$. North is upward. Tick marks representing UTM easting and northing are shown every $2 \mathrm{~km}$. GPS profiles are shown as solid lines, with small solid symbols corresponding lo individual point measurements; these appear as solid heavy lines for the continuous profiles. For McCall Glacier, additional open symbols mark locations optically surveyed in 1972 and 1993. The acquisition dates for map photography and GPS profiles are given for each glacier following the abbreviations " $m$ " and " $p$ ", respectively. Roman numerals indicate the corresponding topographic map in Table 3. Dotted curves represent the new terminus outlines calculated by our volume-change algorithm. Surveyed terminus outlines for different years are shown for W. Okpilak Glacier and McCall Glacier.

We call this the balance-map method; it can be implemented successfully only if the mass-balance network provides sufficient areal coverage.

We also distinguish between net accumulation, which is the net amount of annual precipitation and possibly refrozen melt that is added to the glacier, and winter balance, which is the maximum snow balance on top of the last summer surface in the spring.

All mass balances are given in water equivalent unless otherwise noted and all balances, including long-term averages calculated over several decades, are given as annual values.

\section{MASS-BALANCE RECORD OF McGALL GLACIER}

The mass-balance record on McCall Glacier is fragmented. A few ablation measurements were made in the mid 1950s 
(Keeler, 1958), a new program was initiated in 1969 and continued until 1972 (Trabant and Benson, 1986; Wendler and others, 1972) and our ongoing program began in 1993. These monitoring programs generally involved annual balance measurements using the glaciological method. In addition, average balances over longer periods were determined using the topographic method, as described by Dorrer and Wendler (1976) and Rabus and others (1995). In this section, we present the results of these programs in an internally consistent framework. Because the measurement techniques and methods used to calculate annual balance differed, we first describe the methods by which the basic data were obtained and then describe a re-evaluation of the earlier data within our present framework, along with an analysis of the errors. We are then able to discuss changes in mass balance, focusing on the differences between the 1970s and the 1990s. No annual mass-balance measurements are available from the 1950 s.

\section{Glaciological mass-balance methods: 1970 s}

In 1969, Trabant and Benson (1986) established a network of about 70 mass-balance poles. The heights of the poles were measured monthly from May to September, and snow-pit measurements were made in spring and fall. A fixed hydrological year, beginning 1 October, was used. Glacier-wide net balance was determined, along with the individual components of ice, superimposed ice, internal accumulation and snow. However, the exact computational method used in calculating glacier-wide balances from local balances is not known but most likely the balance-map method was used. They estimated the error in the net balance to be $\pm 5 \mathrm{~cm}$ for the 1970, 1971 and 1972 balances and $\pm 8 \mathrm{~cm}$ for the 1969 balance.

In-situ measurements of internal accumulation were carried out by Trabant and Benson. They monitored the growth of individual ice layers in the firn at specific locations. However, the spatial pattern of internal accumulation was irregular and it was felt that extrapolation to unmeasured areas would be inaccurate. Instead, an indirect method was used. Potential internal accumulation was restricted to areas where the glacier surface was judged to be permeable to water, both meltwater and rainfall. For each pole in this permeable area, a maximum capacity for internal accumulation was calculated using shallow-ice temperatures. The average capacity was about $45 \mathrm{~cm}$ per unit area (water equivalent), with only small spatial and year-to-year variations. The available surface water was calculated from measured summer precipitation plus the difference between the spring snow balance and the autumn firn balance. Internal accumulation was then taken to be the smaller of the available water and the maximum capacity. An important result of this analysis was that the capacity for internal accumulation was usually much larger than the available water (Trabant and Benson, 1986). Therefore, internal accumulation on Arctic glaciers is probably "liquid limited" vs "thermally limited". It was also found that up to $40 \%$ of the net accumulation on the glacier was in the form of internal accumulation, making it a significant contribution to the mass balance of this Arctic glacier.

\section{Glaciological mass-balance methods: 1990 s}

Our mass-balance measurements cover the period 1993-96. A network of 16 poles along the center line of the glacier and in the three cirques was established in mid-June 1993. It was extended to 34 poles in 1995 in an effort to establish an areal coverage similar to that in the 1970s. For each of the four years, the pole heights were measured early in the spring (May to mid-June) and near the end of the ablation season (July-early September). Density profiles of the snowpack were measured in spring and autumn at one-three locations. No autumn density measurements were made in 1994 or 1996.

Contrary to the 1970 s, we used the stratigraphic system to define the balance year in the 1990s. Late-summer surfaces at each pole were determined by probing through the winter snow each spring. With the exception of an area in the upper cirque in 1994, identification of the summer surface was usually unambiguous. Snow balance was measured at each pole and at some additional sites, giving a total of 24-54 locations each year where we determined winter balance.

For the years 1995 and 1996, we established correlations between the local balance measured at the poles within the limited 1993 network (with 16 poles) and that at the additional poles of the extended network. We then used these correlations to extend the limited measurements in 1993 and 1994 to a greater areal coverage in those years. Balance maps were constructed from each year's data, using this extrapolated coverage as needed. All balances for 1993-96 were calculated using this method, sampling the map on a $100 \times 100 \mathrm{~m}$ grid.

A sonic snow-surface sounder was installed at the confluence of the three cirques, somewhat below the mean 1970 s equilibrium line, for measuring accumulation and ablation. Continuous records exist for June 1993-June 1994, and for May-September 1996. These records show that, typically, the ablation season began in the first week of June and ended in mid-August, thus being less than $2 \frac{1}{2}$ months in duration. The maximum snow depth at this location was about $60 \mathrm{~cm}$; this snow and between 25 and $50 \mathrm{~cm}$ of ice were melted during the ablation season. Most of the snowfall occured in late August, September and May; there was little winter precipitation.

Internal accumulation was estimated following a procedure similar to that used in the 1970s. The total available water percolating into the permeable zone was approximated by the spring snow balance minus the autumn firn balance, plus summer precipitation. Rainfall was measured at a precipitation gauge located on the eastern moraine at an elevation of $2100 \mathrm{~m}$. The extent of the permeable zone was delineated from field observations. This provided a relatively crude but consistent estimate of internal accumulation. We discuss this important contribution below.

How do we obtain an error estimate for the balance-map approach? Lliboutry (1974) modeled the mass balance of an individual pole as the sum of three terms: a spatial term, a temporal term and a random error of about $\pm 20 \mathrm{~cm}$. This error incorporates (i) the individual reading error, typically largest in the accumulation area, (ii) the mismatch between the individual pole and the local average, and (iii) extrapolation errors of limited pole networks. Cogley and others (1996) claimed that the error of the glacier-wide balance equals Lliboutry's value for an individual pole. We take a different view point: if the network has sufficient areal coverage, then the error is dominated by the components (i) and (ii). As these errors should be randomly distributed among the poles, the average glacier-wide error should be reduced 
according to $1 / \sqrt{n}$, where $n$ is the number of poles in the network. For example, with 30 poles, we obtain a value of $\pm 4 \mathrm{~cm}$ for an estimate of the random error in annual balance. Insufficient areal representation of the massbalance network and systematic errors in the extrapolation of snow and firn density will somewhat increase this value. Given these and other sources of error, we arrive at $\pm 8 \mathrm{~cm}$ as a conservative error estimate for the annual balances. It applies only to the surface balance, without internal accumulation. Errors in the internal accumulation cannot be analyzed rigorously with the measurements in hand; below we present minimum and maximum scenarios for this contribution.

\section{Re-evaluation of the 1970 s balance data}

In order to ascertain the specific methods utilized with the earlier dataset, and to place all the mass-balance calculations into a consistent framework, we have re-evaluated the glaciological mass-balance data from the 1970s (unpublished information from D. Trabant) under the protocol just described for our 1990s data. First, we calculated the balances using a fixed-date system in order to check our values with those published by Trabant and Benson (1986). These calculations were carried out on the entire dataset of about 70 poles and on a sub-set of the network that was equivalent to the 34 poles measured in 1995-96. We re-evaluated the net balance on these two networks using two approaches (Table 1): balance maps $b_{\text {map }}$ and the balance vs elevation method $\left(b_{\text {elev }}\right)$ with a third-order polynomial fit to the balance curve and an area-elevation curve derived from the 1956 USGS

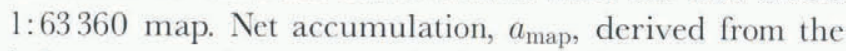
balance maps, is also given in the table. In the last section of Table 1 are listed the published values of these parameters from Trabant and Benson (1986), along with their value of internal accumulation, $a_{(\mathrm{i})}$.

Table 1. Re-evaluation of 1970s mass-balance data (fixeddate system). Units in $\mathrm{cm}$

\begin{tabular}{rrrrrrrrrrr}
\hline & \multicolumn{1}{c}{ 1990s sub-set } & \multicolumn{3}{c}{ Full 1970s net } & \multicolumn{3}{c}{ Published } \\
\hline Year & $b_{\text {map }}$ & $a_{\text {map }}$ & $b_{\text {elev }}$ & $b_{\text {map }}$ & $a_{\text {map }}$ & $b_{\text {elev }}$ & $b$ & $a$ & $a_{(\mathrm{i})}$ \\
& & & & & & & & & & \\
\hline 1969 & -45 & 8 & -41 & -42 & 10 & -43 & -42 & 9.9 & 3.6 \\
1970 & -3 & 23 & -1 & -1 & 28 & -4 & -8 & 19.0 & 5.4 \\
1971 & -10 & 23 & -5 & -5 & 26 & -8 & -14 & 15.8 & 5.6 \\
1972 & -18 & 19 & -24 & -12 & 22 & -20 & -19 & 14.1 & 5.7 \\
& & & & & & & & & \\
\hline
\end{tabular}

There are several points to notice from this table. First, the values that we calculated using only data from the 199596 sub-set agree with those from the full network to within $\pm 5 \mathrm{~cm}$. This suggests that the sub-set provides adequate areal coverage. Secondly, $b_{\text {map }}$ generally agrees with $b_{\text {elev }}$ to within one standard error $( \pm 8 \mathrm{~cm})$, an encouraging result given the complex shape of the mass-balance contours on these maps (Fig. 3). Thirdly, the agreement between the recalculated values and those listed by Trabant and Benson (1986) is within the standard error but, because we used the same data, it is somewhat surprising that the agreement is not better. These differences do imply that a re-evaluation under our framework is necessary for developing an internally consistent analysis of the mass-balance record.
To facilitate this, we treated the 1970 s data in exactly the same way as those of the $1990 \mathrm{~s}$. We first transformed the individual pole balances from the fixed-date system into the stratigraphic system, subtracting the difference of the initial and final snow balances for the balance year. We then used the balances for those poles in the 1995-96 sub-network to construct balance maps for the years 1969-72.

\section{Results for the combined mass-balance record 1970 s and 1990s}

The combined mass-balance record for the periods 1969-72 and 1993-96 in the stratigraphic system is given in Table 2. The first two data columns show the surface balance $b_{(\mathrm{s})}$ and its corresponding accumulation area ratio (AAR). The following columns show net balance $b$, net accumulation $a$, internal accumulation $a_{(\mathrm{i})}$, and the net balance AAR and ELA. For the 1990s, the net values are given for minimum and maximum calculations of internal accumulation, which are discussed below. $b_{\mathrm{w}}$ and $p_{\mathrm{s}}$ are quantities needed for these calculations; $b_{w}$ denotes the maximum winter balance, which we approximate by the snow balance on the date listed, and $p_{\mathrm{s}}$ is the summer precipitation measured at our precipitation gauge between the date listed and 10 August, the last day of significant melt. The ELA is an average elevation for the equilibrium line; the actual line of zero balance often spans about $300 \mathrm{~m}$ in elevation, as already noted.

The 4 year average annual surface balance was $-29 \pm 3$ $\mathrm{cm}$ from 1969 to 1972 and $-63 \pm 3 \mathrm{~cm}$ from 1993 to 1996 , indicating a pronounced trend towards more negative surface balances from the 1970 s to the 1990s. This trend is apparent despite the inclusion of the exceptionally cold year 1996, which had the most positive balance ever measured on McCall Glacier. The balance maps for the surface balances 1969-72 and 1993-96 are shown in Figures 3 and 4, respectively. In the $1970 \mathrm{~s}$, the lower (western) cirque was always an area of accumulation and maximum ablation near the terminus was always less than $180 \mathrm{~cm} \mathrm{a}^{-1}$. In contrast, the years 1993-95 were characterized by considerable ablation of old firn and ice in the lower cirque and a maximum ablation of more than $200 \mathrm{~cm} \mathrm{a}^{-1}$ near the terminus. In 1994, the year with the most negative surface balance, maximum ablation exceeded $350 \mathrm{~cm}$. For these 3 years, firn accumulation was restricted to two small regions in the centers of the upper and middle cirques. In contrast, 1996 was more similar to the 1970s regarding the patterns of firn accumulation and ablation. Examination of the balance maps (Figs 3 and 4) confirms that there is no meaningful definition of a specific ELA on McCall Glacier.

From a climatological point of view, it is the surface balance of an Arctic glacier that corresponds to the usual mass balance of warmer temperate glaciers, which is given as the simple difference between summer ablation and winter accumulation. The net balance of an Arctic glacier additionally includes internal accumulation and therefore also depends on other factors, such as mean winter temperature, the permeability of the glacier surface to water and rainfall on the snowpack. We require both surface and net balances to calibrate the mass-balance model presented in a later section, and thus we need an accurate estimate of internal accumulation in the 1990s.

\section{Scenarios of internal accumulation}

Because internal accumulation is difficult to measure di- 


\begin{tabular}{lrrrrrrr}
\hline Year & $b_{\mathrm{s}}$ & $A A R$ & $b$ & $a$ & $a_{(\mathrm{i})}$ & AAR & ELA \\
\hline & & & & & & & \\
1969 & -53 & 0.27 & -45 & 10 & 8 & 0.34 & 2150 \\
1970 & -13 & 0.62 & -4 & 23 & 9 & 0.62 & 1940 \\
1971 & -23 & 0.47 & -12 & 20 & 11 & 0.48 & 2070 \\
1972 & -25 & 0.45 & -14 & 23 & 11 & 0.47 & 2060
\end{tabular}

b $\quad a \quad a_{(\mathrm{i})} \quad A A R \quad$ ELA

\begin{tabular}{|c|c|c|c|c|c|c|c|c|c|c|c|c|c|c|c|}
\hline \multirow[b]{2}{*}{1993} & \multirow[b]{2}{*}{-72} & \multirow[b]{2}{*}{0.07} & \multicolumn{5}{|c|}{ Minimum internal accumulation } & \multicolumn{5}{|c|}{ Maximum internal accumulation } & \multirow{2}{*}{$\begin{array}{l}\text { Date } \\
6-30\end{array}$} & \multirow{2}{*}{$\begin{array}{l}b_{w} \\
17\end{array}$} & \multirow{2}{*}{$\begin{array}{r}p_{8} \\
12.9\end{array}$} \\
\hline & & & -69 & 4 & 3 & 0.07 & 2290 & -50 & 9 & 22 & 0.30 & 2190 & & & \\
\hline 1994 & -102 & 0.08 & -99 & 5 & 3 & 0.08 & 2340 & -77 & 8 & 25 & 0.22 & 2260 & $6-30$ & 26 & 12.8 \\
\hline 1995 & -73 & 0.02 & -72 & 1 & 1 & 0.02 & 2400 & -5.5 & 5 & 18 & 0.18 & 2330 & $6-25$ & 9 & 13.4 \\
\hline 1996 & -4 & 0.52 & 1 & 25 & 5 & 0.53 & 1990 & 3 & 27 & 7 & 0.58 & 1970 & $5-6$ & 20 & 11.5 \\
\hline
\end{tabular}

All mass balances are in cm, ELA in $\mathrm{m}$ and AAR dimensionless.

rectly (Trabant and Mayo, 1985), we estimate it. Near-surface firn temperatures in the 1990s were similar to those in the 1970 s, and thus the capacity for internal accumulation
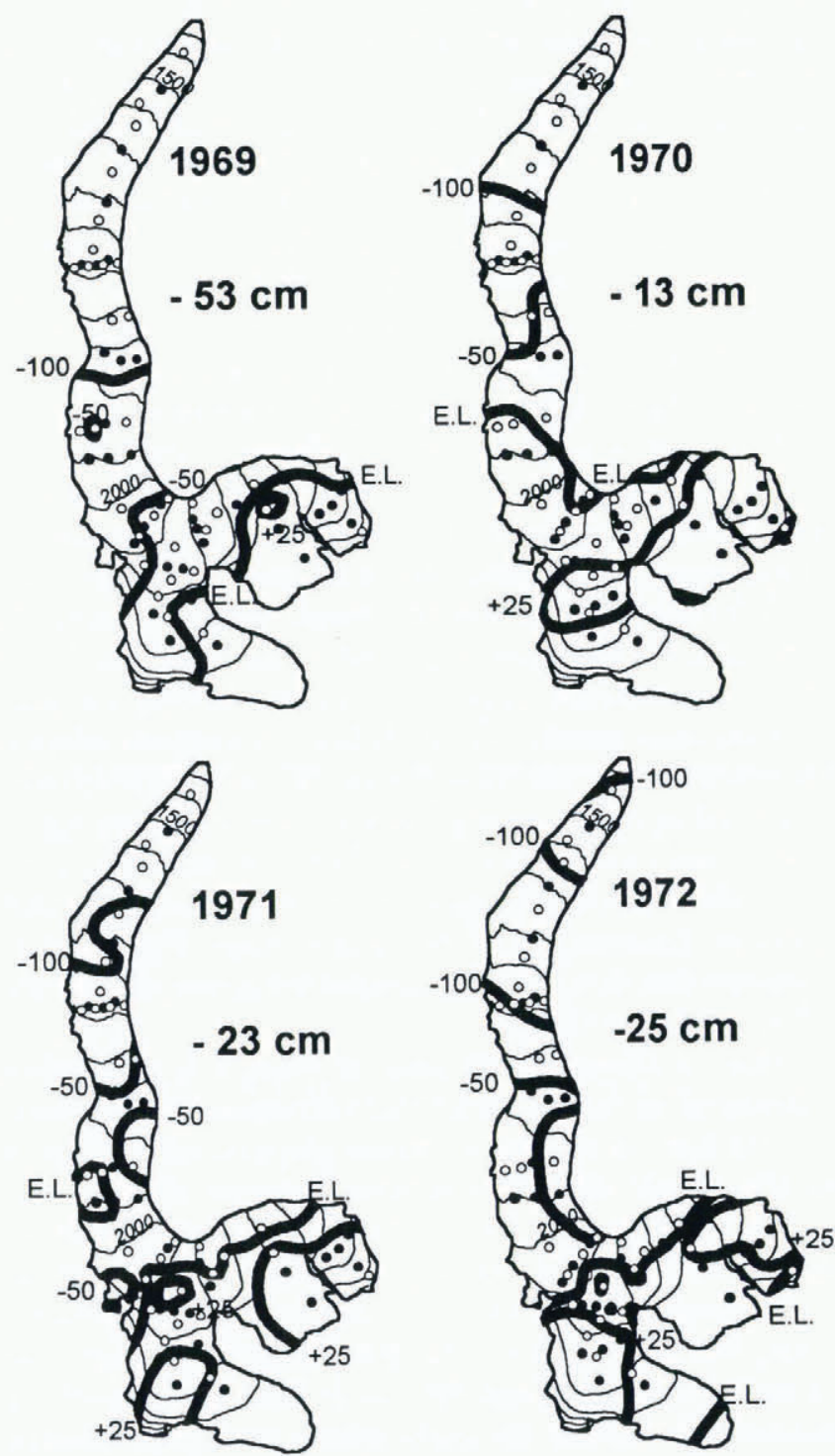

Fig. 3. Balance maps of the stratigraphic surface mass balance, 1969-72. Contours of equal mass balance are shown for $-200,-100,-50,0,+25$ and $+50 \mathrm{~cm}$ water equivalent. The $0 \mathrm{~cm}$ contour is the equilibrium line (E.L.). Glacier-wide annual balances are noted. should be approximately equal to its mean value determined in the 1970 s (Trabant and Benson, 1986). We then propose two possible scenarios for the extent of the glacier
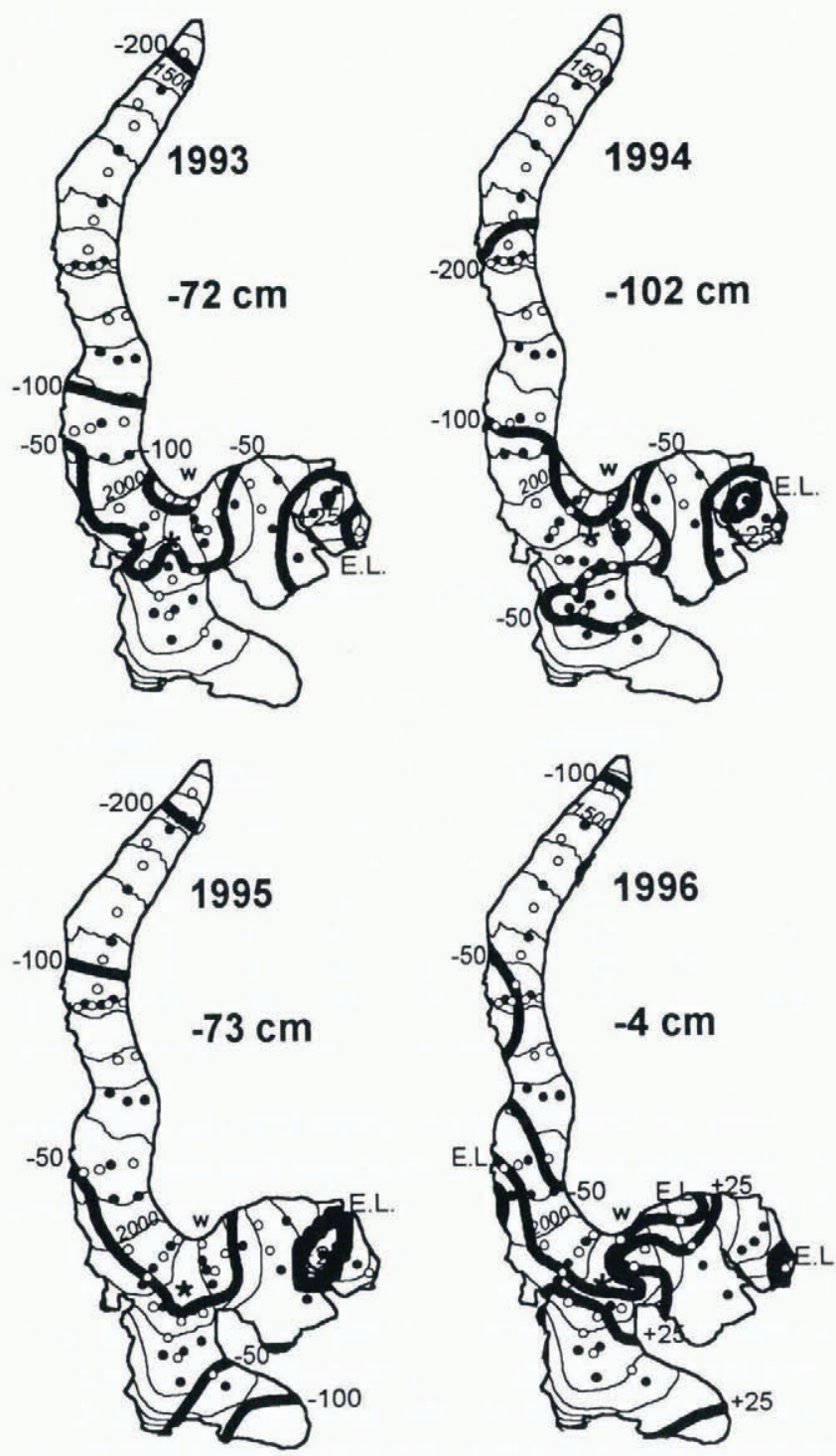

Fig. 4. Balance maps of the stratigraphic surface mass balance, 1993-96 (contour labels as in Figure 3). Glacierwide balances are noted. The asterisk showe the location of the sonic ranger. 
surface where internal accumulation may occur the "permeable zone"): (1) an area equal to the region of positive firn balance in a given year, and (2) an area equal to the permeable zone in the 1970 s. Scenario 1 provides a minimum estimate of internal accumulation, while 2 provides a maximum estimate for the 1990s. We begin with a discussion of these different assumptions.

In the 1970 s, the area assumed to be permeable was approximately equal to the area of firn accumulation (i.e. where the local surface balance was positive). For the years 1993-95, accumulation of new firn was negligible, with surface-balance AARs as small as 0.02 . Under these conditions, scenario (1) leads to very small amounts of internal accumulation (Table 2, column 6).

Scenario (2) involves considerable internal accumulation outside the area of new firn accumulation in the 1990s and, as such, is a maximum estimate. It is important to note that internal accumulation need not be restricted to areas of the surface that are porous in a microscopic sense. For example, Sater (1959) noticed that a large number of small crevasses (5-20 cm wide) opened in the upper ablation area during the cold winter months, but they were closed by refreezing of water in summer. This process acts as a sink for internal accumulation in the early melt season. It also makes the surface impermeable to water in the late melt season. We note that for years 1993-95 internal accumulation exceeds net accumulation under this scenario (Table 2, columns 11 and 10). This is a direct result of the large amount of old firn that is ablated and becomes run-off in the late melt season, along with some melt of the early season internal accumulation. For 1996, maximum and minimum scenarios of internal accumulation are similar, with internal accumulation being about $25 \%$ of the net accumulation. This is similar to that observed in the 1970 s mainly because the permeable zone actually had about the same extent during these time periods.

The large contribution of internal accumulation to the mass balance of Arctic glaciers such as McCall Glacier is significant because estimates of water released by these glaciers to sea-level rise may need to be re-evaluated if based solely on surface-balance measurements. This has been discussed by Pfeffer and others (1990) in application to the Greenland ice sheet.

\section{Topographic mass-balance measurements}

Cumulative net mass balances for the time intervals between the field programs can be determined using glacier surface-elevation data obtained by photogrammetry or surveying; these cumulative balances can then be divided by the number of years in the intervening time to give the average net balance over each interval. Comparison of these long-term topographic balances with the net balances presented above then gives a picture of mass-balance trends during the last 40 years. The long-term average balances also provide useful constraints on the mass-balance modeling described in a later section.

A direct photogrammetric comparison by Dorrer and Wendler (1976) gave a value of $-13 \mathrm{~cm}$ for the long-term average annual balance from 1958 to 1971, a somewhat less negative value than the average of the $1970 \mathrm{~s}$ net balances $(-19 \mathrm{~cm})$. In another study, Rabus and others (1995) compared the elevations at about 60 locations on the glacier surface, as surveyed in 1972 (personal communication from D.
Trabant), with a 1958 topographic map (American Geographical Society, 1960). However, there are large systematic errors in the 1958 topographic map and, thus, it was difficult to make a reliable estimate for the 1958-72 mass balance using this method. While we cannot directly evaluate the errors in Dorrer's (1975) analysis (that method did not involve the 1958 map), we believe them to be smaller than those associated with the 1958 map. As an independent check, we have also compared the above-mentioned 1972 vertical elevations with a 1:63360 scale topographic map produced by the U.S. Geological Survey (USGS) from 1956 photography. Despite the larger error inherent in the coarser contour interval ( $100 \mathrm{ft}$ or $30.5 \mathrm{~m}$ ), this comparison gave an estimate of $-17 \pm 6 \mathrm{~cm}$ for the long-term average balance from 1956 to 1972 . This value is close to that of Dorrer and Wendler (1976) and, combining the two estimates, we obtain a value of $-15 \pm 5 \mathrm{~cm}$ for the 1958-72 average annual net balance.

By resurveying the 1993 surface elevation at the same positions used in 1972, Rabus and others (1995) determined the average annual net mass balance for the period 1972-93 to be $-33 \pm 1 \mathrm{~cm}$. This is significantly more negative than the 1958-72 average balance of $-15 \pm 5 \mathrm{~cm}$, thus giving further support to a change in climate in this region.

In June 1995, the surface elevations at about 40 of these positions were again resurveyed. Combination of these data with snow depths at each site allowed us to calculate the volume change, and thus make a topographic estimate of the average mass balance for 1993 and 1994. Using a density of $0.90 \mathrm{Mg} \mathrm{m}^{-3}$ to convert ice to water equivalent, an annual value of $-65 \pm 6 \mathrm{~cm}$ was obtained for these 2 years. (This value of density may introduce a slight bias toward a more negative balance because there was significant ablation of old fin during both years (Krimmel, 1989).)

We can compare this average 1993-94 balance with those presented in Table 2 under the different scenarios of internal accumulation. Taking the average of the 1993 and 1994 balances in this table, we find $\left\langle b_{(\mathrm{s})}\right\rangle=-87 \pm 8 \mathrm{~cm}$, $\left\langle b_{(\min )}\right\rangle=-84 \pm 8 \mathrm{~cm}$ and $\left\langle b_{(\max )}\right\rangle=-63 \pm 6 \mathrm{~cm}$ for the 1993-94 period. The close agreement between the latter value and the topographical value $(-65 \pm 7 \mathrm{~cm})$ implies that the scenario that predicts maximum internal accumulation is probably more realistic. Comparison of the glaciological surface balance and topographical balance yields a value of $22 \mathrm{~cm}$ for the mean annual internal accumulation over this 2 year period. These results suggest that the zone of permeability, where internal accumulation occurs, is much larger than the area of firn formation during warm summers. This further suggests that alternative processes of internal accumulation, such as refreezing of water in crevasses, may be important.

In a similar study, Haakensen (1986) has found that long-term topographic balances and cumulative surface balance on an Arctic glacier in Norway differ by about $14 \mathrm{~cm}$, while these two types of balance agree quite well for the more temperate glaciers he studied. Haakensen interpreted these differences as internal accumulation of an amount equal to $14 \mathrm{~cm} \mathrm{a}^{-1}$.

\section{Record of net mass balance and possible implica- tions}

In Figure 5 we compile the various net balances discussed above. The maximum scenario of internal accumulation 


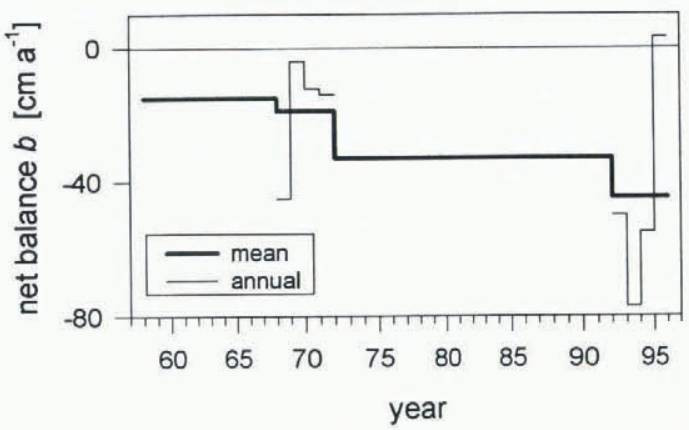

Fig. 5. Net mass-balance record of $M c$ Call Glacier. The record is combined from the topographically determined long-term average values, 1957-72 and 1972-93, and the average balances during the 4 year periods 1969-72 and 1993-96 (bold line). The individual annual net balances are also shown (thin line).

was used for the 1990s (right side of Table 2). A strong trend toward increasingly negative mass balances stands out clearly, with high inter-annual variability about this trend. An even more negative trend would be shown if the minimum scenario for internal accumulation were used.

By applying an approximate mass-balance model to a variety of glacierized regions, Oerlemans and Fortuin (1992) found an empirical relation, $\Delta b_{(1 \mathrm{~K})}=-0.512-0.662$ $\log _{10}(P)$, between the mean annual precipitation, $P$ (about $0.5 \mathrm{ma}^{-1}$ on McCall Glacier), and the mass-balance response $\Delta b_{(1 \mathrm{~K})}$ of a glacier to a uniform $1 \mathrm{~K}$ increase in mean annual temperature. If we assume that the observed changes in average net balance, $\Delta b$, on McCall Glacier are caused by a uniform change in temperature, and that the precipitation is nearly constant, then we can use Oerlemans and Fortuin's model to estimate the causal temperature change as $\Delta T=1 \mathrm{~K} \times\left(\Delta b / \Delta b_{(1 \mathrm{~K})}\right)$. From $1957-72$ to 1972 93, we find an estimated increase of $0.6 \mathrm{~K}$ in air temperature for this $20+$ year interval. (Similarly, we would obtain an additional $0.4 \mathrm{~K}$ temperature increase from 1972-93 to 1993-96; however, the short duration of the later period makes this estimate unreliable). Of course, the precipitation need not be constant over these intervals.

\section{(a) 1970s}

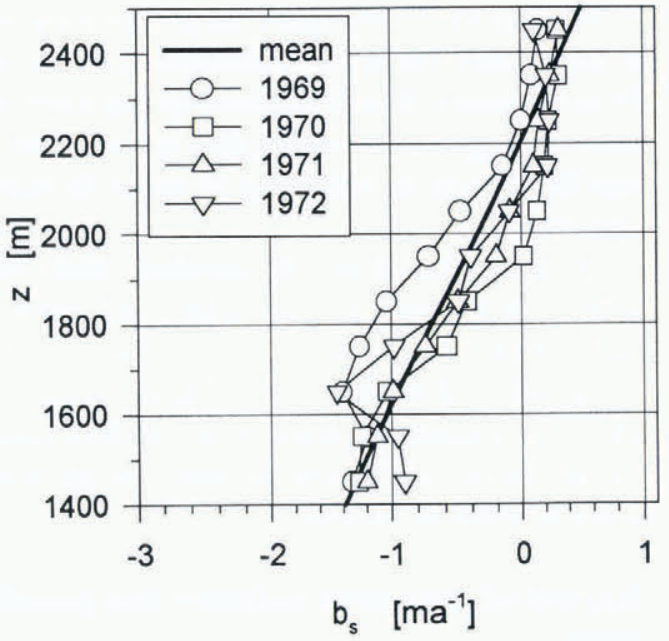

\section{Mass-balance gradient}

The gradient of local surface balance with elevation reflects the climatic regime of a glacier. A long-term change in the balance gradient may indicate a change in the climate towards one which is more continental or more maritime (e.g. Oerlemans and Hoogendorn, 1989). To investigate this possibility, the annual surface balance as a function of elevation was calculated from the balance maps in Figures 3 and 4. For each of the two time periods we used the concurrent surface elevation, thus taking into account the significant thinning since the 1970s. The results are shown in Figure 6. Since the 1970 s there has been an increase in the variability of the local mass balance. Linear regression of the massbalance curves as a function of (concurrent) elevation for the 1970 s and for the 1990 s gives the heavy lines shown in these figures. The average annual balance gradient for the 1970s was $172 \pm 4 \mathrm{~cm} \mathrm{~km}^{-1}$ and $201 \pm 6 \mathrm{~cm} \mathrm{~km}^{-1}$ for the 1990s. Without the exceptionally cold year in 1996, the balance gradient in the 1990 s would be slightly higher $\left(210 \mathrm{~cm} \mathrm{~km}^{-1}\right)$. We conclude that there has been a significant increase in the balance gradient on McCall Glacier from the 1970 s to the $1990 \mathrm{~s}$. A possible interpretation is a larger mass exchange in the $1990 \mathrm{~s}$, with the more negative balances being caused by a disproportionate increase of ablation at lower elevations. The mass-balance modeling described in a later section lends further support to such a change.

\section{REGIONAL REPRESENTIVITY OF McCALL GLA- GIER MASS BALANGE}

The data from McCall Glacier comprise the only long-term record in Arctic Alaska. One may question how representative this record is in a regional context. To investigate whether the trends in the McCall Glacier balance reflect a coherent regional signal, we measured changes in surface elevation along the center lines of ten other glaciers in the northeastern Brooks Range (Fig. 1). Our surveys were carried out once on each glacier during the period 1993-95, and the elevation changes with respect to 1956 or 1973 topographic maps were used to estimate long-term mass balances over the intervening time period.

\section{(b) 1990s}

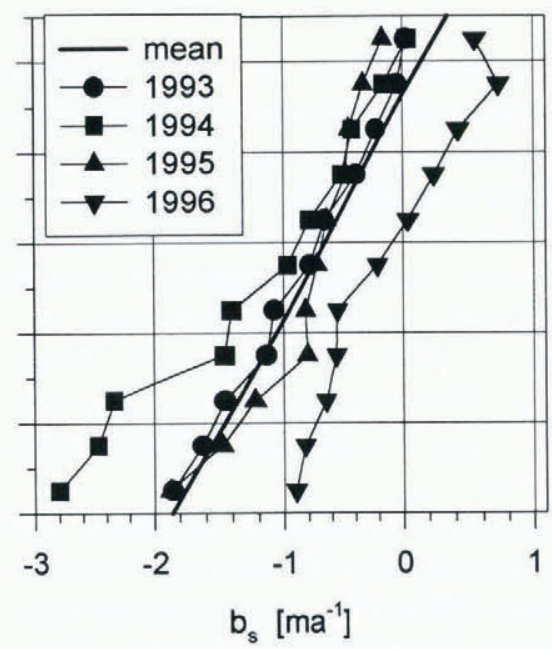

Fig. 6. Surface mass balance $b_{\mathrm{s}}$ as a function of elevation $z$ : (a) for the period 1969-72, and ( b) for the period 1993-96. For both periods, $z$ is the actual surface elevation at that time. In each case, the heavy line represents a linear least squares fit of all four massbalance curves $b_{\mathrm{s}}(z)$. 
The surveyed glaciers fall into three morphological groups (Fig. 2): larger valley glaciers (McCall, Esetuk and the two Okpilak Glaciers), smaller valley glaciers (Arey, Wolverine Crag, Gooseneck, Bravo and the two Hubley Glaciers, and one cirque glacier (Hanging Glacier). The distance from McCall Glacier to Arey Glacier is about $5 \mathrm{~km}$, and about $20 \mathrm{~km}$ to Esetuk and the two Okpilak Glaciers. All the other glaciers are immediate neighbors of McCall Glacier, that is, their drainage basins are within or have a common border with the McCall Glacier drainage basin.

\section{Topographic maps}

Four adjacent USGS maps of scale 1:63360 and a contour interval of $100 \mathrm{ft}(30.5 \mathrm{~m})$ were used in this analysis. The datum of the maps is NAD27, with elevation given above mean sea level. Mapping photography was acquired in two different years: 1956 and 1973. The maps for each glacier, numbered I to IV, and the dates of photography are given in Tables 3 and 4 .

Three significant error sources can be present in the elevation contours of these maps (Echelmeyer and others, 1996): (i) a random error on the order of $\pm 15 \mathrm{~m}$, (ii) local systematic errors in regions where the photographs have

Table 3. Measured elevation offsets for the topographic map sheets of this study

\begin{tabular}{lllllll}
\hline $\begin{array}{l}\text { USGS1:63360 No. } \\
\text { Quadrangle }\end{array}$ & Sheet & $\langle\Delta z\rangle$ & $\sigma$ & $n$ & Method \\
& & & & & \\
& & $\mathrm{m}$ & $\mathrm{m}$ & & \\
& &
\end{tabular}

\begin{tabular}{lllrrrrl}
\hline & & & & & & & \\
Demarcation point & B5 & I & 1956 & +1 & 3 & 5 & Spot \\
Mount Michelson & BI & II & 1956 & +20 & 13 & 54 & Profile \\
& & & & +22 & - & 1 & Spot \\
Mount Michelson & AI & III & 1973 & +17 & - & 1 & Spot \\
& & & & -2 & 6 & 5 & Profile \\
& & & & -14 & 3 & 4 & Profile \\
Demarcation point & A.5 & IV & \multirow{2}{*}{1956} & - & - & - & None \\
\hline
\end{tabular}

Table 4. Mass-balance and terminus changes, 1956 or 1973 to present, of 11 Brooks Range glaciers poor stereoscopic quality, and (iii) a systematic offset between the map and the true elevation. The latter errors can be on the order of $20 \mathrm{~m}$ because geodetic control for the photogrammetry was extremely sparse in this part of North America.

The random error will cause fluctuations about a smooth curve of elevation change vs elevation on a glacier, but its effect on the cumulative mass balance (as an areaweighted average of elevation change) is reduced by the square root of the number of contours considered (Echelmeyer and others, 1996).

Potential systematic offsets for each map were identified in two ways: either we surveyed the true elevation of topographic highs that were labeled to $\pm 10 \mathrm{ft}(3 \mathrm{~m})$ on the maps ("spot elevations") using static Global Positioning System (GPS) methods, or we made airborne laser/GPS profiles (Echelmeyer and others, 1996) over bedrock surfaces and evaluated the elevation difference between the profiled bedrock and the map contours. A geoid model (Alaska 94) was used to relate these ellipsoid heights to mean sea level. Mean vertical deviations, $\langle\Delta z\rangle$, between our surveys and the map elevations are given in Table 3 for both the spot elevations and the bedrock profiles. The corresponding standard deviation, $\sigma$, and the number of surveyed points, $n$, are also shown. The GPS elevations have an accuracy of $0.5 \mathrm{~m}$ or better.

No significant vertical offset was found for map I. Both spot elevations and profile data show that map II is consistently $20 \pm 2 \mathrm{~m}$ higher than the measured elevations. The situation on map III is somewhat more complex. A spot measurement made a few kilometers south of West Okpilak Glacier shows the map is $17 \mathrm{~m}$ higher than the measured value, while profile measurements made about $10 \mathrm{~km}$ north of the glacier indicate that the map is $14 \mathrm{~m}$ lower than expected. In the immediate vicinity of the glacier terminus we find that the map is $2 \pm 3 \mathrm{~m}$ lower than the profiled surface. The interpretation of this pattern as a ramp-like north-south offset clearly needs more survey data. In lieu of such data, we assume a zero constant offset $(\Delta z \approx 0 \mathrm{~m})$ for this map in the vicinity of West Okpilak Glacier. Map IV was not field-checked and we used $\Delta z \approx 0 \mathrm{~m}$ from the adjoining map (III). These choices assure similar small ele-

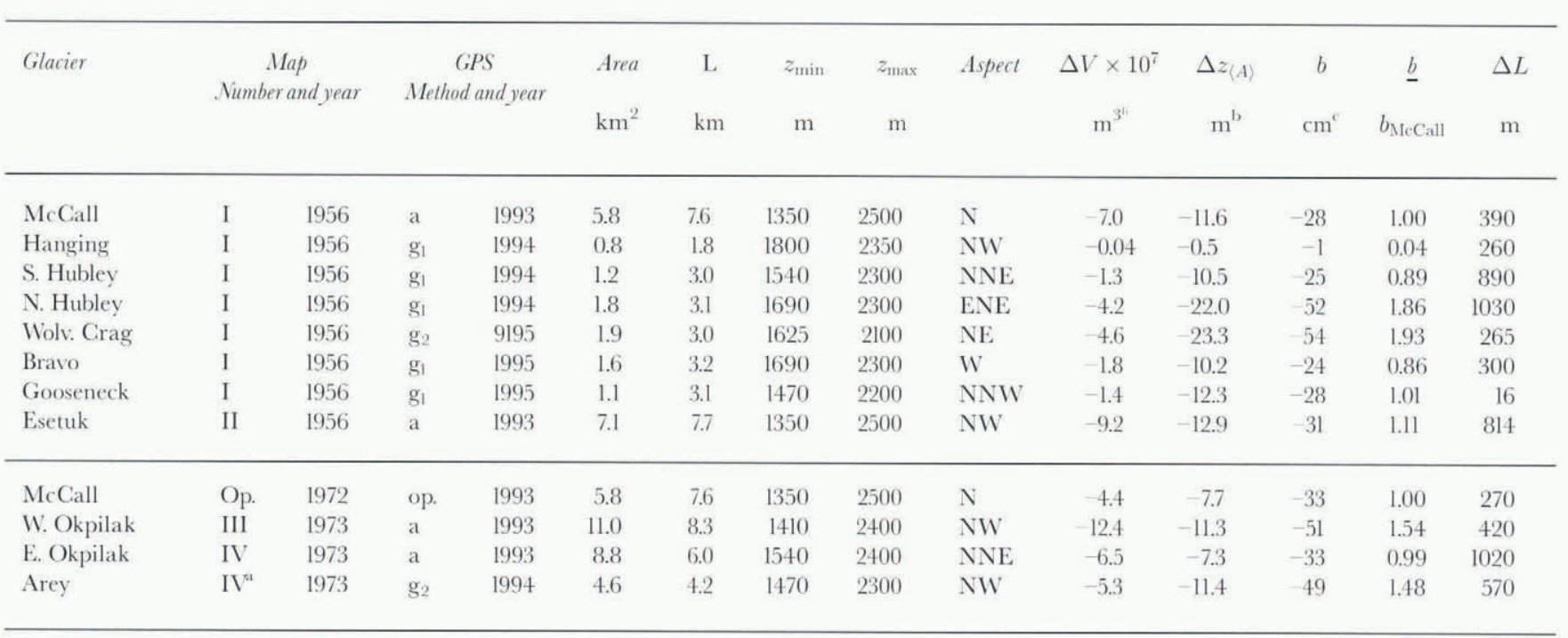

\footnotetext{
a The immediate snout area of Arey Glacier is located on map: 156.

b Ice equivalent over entire time period.

"Water equivalent, annual average.
} 
vation changes in the upper accumulation areas of both West and East Okpilak Glaciers. The mean offsets for each map were used to correct map contour elevations.

Local systematic errors can be identified by unreasonable deviations in the elevation-change curves of the different glaciers. Also, we have examined the actual mapping photographs for areas of poor contrast. In most cases, these local errors appear to be relatively small. However, their effect on the cumulative balance depends crucially on the area distribution of a particular glacier, as errors in extensive accumulation areas can strongly influence such massbalance calculations.

\section{Survey methods}

Three different GPS-based methods were used to survey the center-line elevations and termini of the glaciers. In 1993, an airborne profiling system was used (Echelmeyer and others, 1996). The horizontal and vertical accuracies of this system are about $\pm 0.3 \mathrm{~m}$. In 1994 and 1995, we used two different ground-based methods. The more accurate $( \pm 0.3 \mathrm{~m})$ involved continuous kinematic GPS profiling while skiing down the glacier. The second method utilized a lightweight differential GPS system to determine the coordinates of specific points along a center-line profile relative to a nearby benchmark. The vertical accuracy of this latter method was \pm 3 to $\pm 8 \mathrm{~m}$, depending on conditions.

\section{Elevation and volume change}

The ground tracks of the profiles on each glacier are shown in Figure 2, superimposed on topographic maps. Profiles of Arey and Wolverine Crag Glaciers consist of isolated survey points acquired with the less accurate ground-based method discussed above. On the other glaciers, the profiles were acquired with either the airborne or the high-accuracy ground-based methods, with points spaced every $1-1.5 \mathrm{~m}$ along the profile.

Horizontal coordinates of each GPS profile were transformed from the WGS84 datum to the map datum (NAD27). Vertical height above the ellipsoid was transformed to elevation above mean sea level using the Alaskan geoid model. The geoid separation above the ellipsoid in our study area varies between +3 and $+6 \mathrm{~m}$.

Elevation change was obtained by determining the elevation at each point where the profile intersected a map contour line. Cubic-spline interpolation was used between the data points on Wolverine Crag and Arey Glaciers. The random error of elevation change is dominated entirely by the $\pm 15 \mathrm{~m}$ random error in the map contours. Even in the case of the less accurate GPS method, the combined error is only slightly larger, $\pm 17 \mathrm{~m}$.

To determine the change in glacier volume using a single longitudinal profile on each glacier, we assumed that the elevation change at each contour was constant across the width of the glacier. As the glacier thinned or thickened, its width, and therefore area, would also change. We estimated this change in width by multiplying the elevation change along a specific contour line by the cotangent of the slope of the valley walls at that contour. The projected 1990s outlines of each glacier, as determined using this algorithm, are shown in Figure 2 as dotted lines. The terminus outlines of McCall and West Okpilak Glaciers were also surveyed to a horizontal accuracy of $\pm 2 \mathrm{~m}$ using GPS methods. There was satisfactory agreement between these surveyed glacier outlines and those calculated by our algorithm.

Volume change was then calculated following the method of Finsterwalder (1954). The area-averaged thickness change was obtained by dividing the total change in volume by the area of the glacier, here taken to be the average of the mapped area and the 1990s area. The average net mass balance (water equivalent) was calculated by dividing by the time interval and assuming a density of $0.90 \mathrm{Mg} \mathrm{m}^{-3}$, thus taking the density distribution with depth to be constant.

A rigorous error estimate for the volume-change calculation involving a single center-line profile is difficult to obtain (e.g. Sapiano and others, 1998). We estimated this error from the following analysis of the McCall Glacier data: elevation changes along two center-line profiles, one descending from the upper cirque and the other from the lower cirque, were determined using the optical survey data from 1972 and 1993 (open symbols on the McCall Glacier map in Figure 2). These elevation changes were then used to calculate the cumulative balance from 1972 to 1993 , and the results were compared to those from a two-dimensional interpolation of the entire set of surveyed positions, including all those off the center line (Rabus and others, 1995). The profiles yielded an average change of $-7.6 \mathrm{~m}$ of water, which agrees within $10 \%$ of the value $-6.9 \mathrm{~m}$ quoted by Rabus and others (1995). A similar error estimate on another glacier was obtained by Sapiano and others (1998) using a different method.

The contribution of local systematic errors was investigated by comparing the volume change for a smoothed elevation-change curve with that for the original unsmoothed curve. In most cases, the difference in volume change was less than $10 \%$. In the case of West Okpilak Glacier, where the difference was greater than $10 \%$, we used the smooth version of the curve.

\section{Results}

Elevation changes on these different glaciers are shown as a function of 1990s elevation in Figures 7 and 8 for the two periods 1956-93 and 1973-93, respectively. In both figures the plot in the upper lefthand corner shows the average elevation change for all the glaciers in the time period considered (solid line), along with one standard deviation about this average (light gray) and the envelope of all values of elevation change for the glaciers (dark gray). This plot is useful in determining how meaningful the average elevation change is. All glaciers show strong thinning at lower elevations and a decrease in the magnitude of this thinning with increasing elevation. For 1956 to the 1990s, the average elevation change was about $-60 \mathrm{~m}$ at $1400 \mathrm{~m}$ and about $-14 \mathrm{~m}$ at $2000 \mathrm{~m}$; they were about $15 \mathrm{~m}$ smaller for the period from 1973 to the 1990 s.

For all other plots in Figures 7 and 8, the elevation change on the individual glaciers is compared to the average elevation change for all glaciers over the same time period. For the period 1956-93 (Fig. 7), the elevation changes of Esetuk, Gooseneck, Bravo and South Hubley Glaciers agree well with those on McCall Glacier. North Hubley and Wolverine Crag Glaciers show significantly larger elevation changes than those observed on McCall Glacier. During the 1973-93 period (Fig. 8), elevation changes on West and East Okpilak and Arey Glaciers were similar to those on 

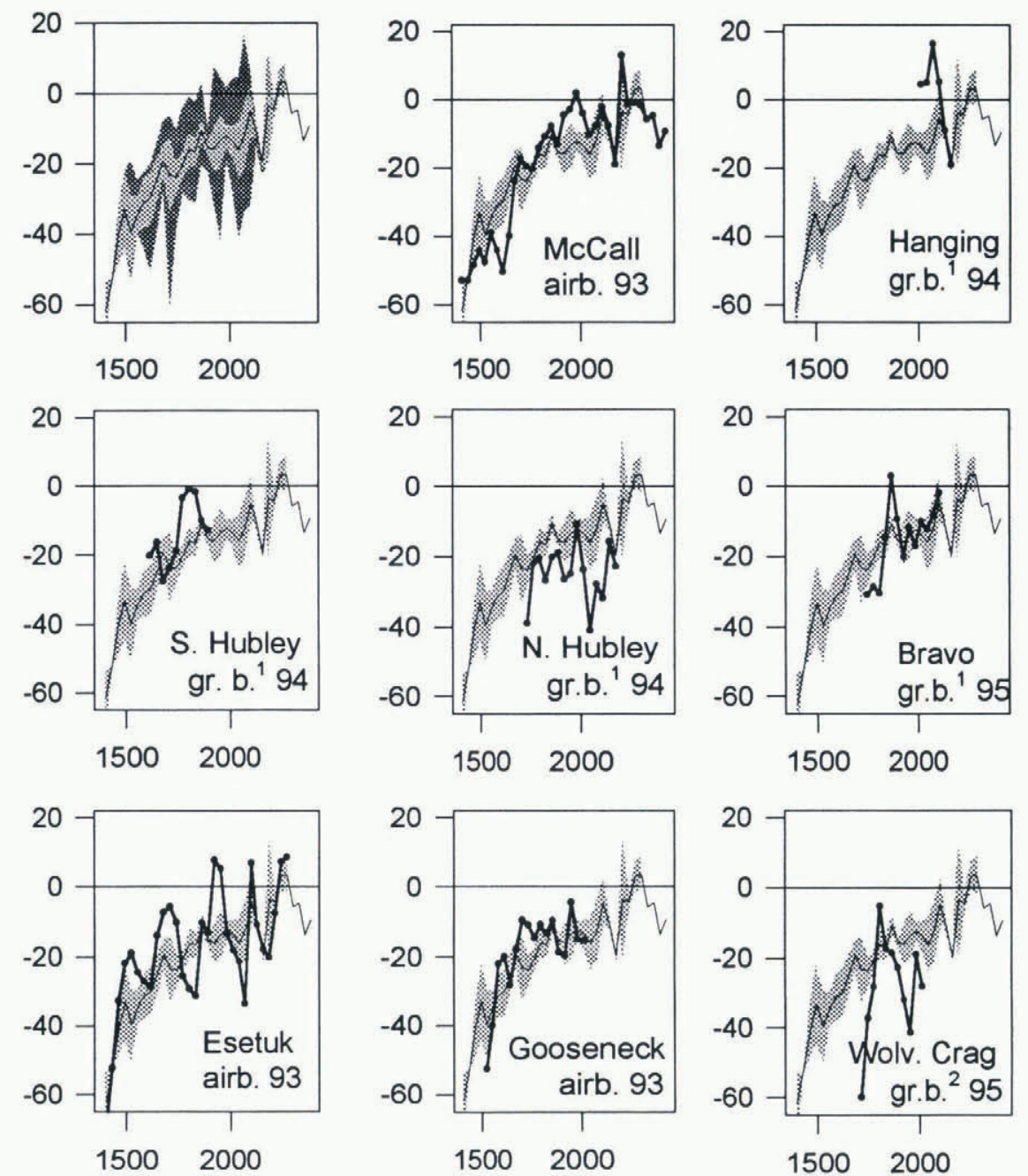

Fig. 7. Elevation change (in $m$ ) between 1956 topographic maps and recently surveyed center-line profiles of McCall Glacier and seven neighboring glaciers as a function of elevation (in $m$ ). The upper left panel shows the mean elevation change for all glaciers (solid line), one standard deviation (light gray) and the maximum spread of elevation change (dark gray) about this mean. The other panels compare the individual elevation changes (heavy curve and symbols) with the mean for all glaciers (thin line). The survey method and acquisition date of the individual profiles is indicated., with abbreviations "airb." "gr.b.1", "gr.b.2" for airborne, high-accuracy ground-based and low-accuracy ground based GPS methods, respectively.
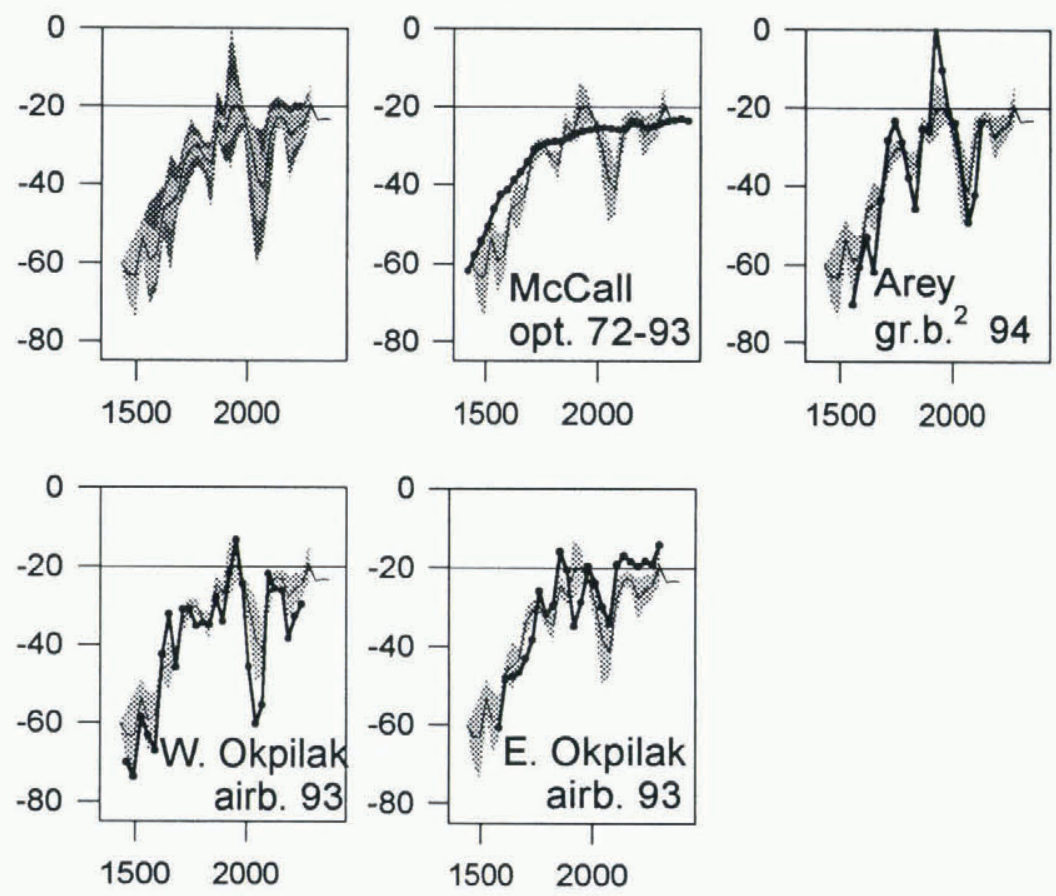

Fig. 8. Elevation change (in $\mathrm{m}$ ) between 1973 topographic maps and recently surveyed center-line profiles of Mc Call Glacier and three neighboring glaciers as a function of elevation (in $\mathrm{m}$ ). Explanations are the same as in Figure 7 . The additional abbreviation "opt." stands for optical surveying, which was used in 1972 and 1993 to calculate the elevation change on McCall Glacier. 
McCall Glacier. Table 4 contains further results on the different glaciers. The first part of this table shows the dates of survey and the methods used, and geometric parameters of the glaciers, including mean glacier area $A$, glacier length $L$, elevation of the terminus $\left(z_{\min }\right)$ and head of the glacier $\left(z_{\max }\right)$, all at the time of mapping; and the mean aspect of the glacier. The second part of the table gives the volume change, $\Delta V$, the area-averaged elevation change for the time period, $\Delta z_{\langle\mathrm{A}\rangle}$, the long-term average net balance, and the change in terminus position, $\Delta L$, from the date of mapping to the 1990s. In order to assess the representivity of McCall Glacier, we have also calculated the ratio of the mass balance of the study glaciers to that for McCall Glacier (second to last column of Table 4). Values range from 0.04 to 1.9 . However, the majority of glaciers had values of $1.0 \pm 0.2$, that is, their average mass balances are within $20 \%$ of the McCall Glacier balance. Four of the glaciers have somewhat more negative balances of around $-50 \mathrm{~cm}$, while the smaller cirque glacier (Hanging Glacier) was close to equilibrium.

The observed variations in mass balance between "anomalous" and "normal" glaciers could reflect corresponding differences in geographic location, area-altitude distribution, aspect or size (e.g. Tangborn and others, 1990). However, for the northeast Brooks Range glaciers, we found no indication of any simple relationship between mass-balance variations and any of these factors.

In summary, the data from the various glaciers indicate that the mass-balance trends of McCall Glacier are representative for the region of the northeastern Brooks Range. Most of the glaciers studied show an overall thinning at the rate of $30-40 \mathrm{~cm} \mathrm{a}^{-1}$ (ice). Pelto (1996) has reported a similar uniformity in the annual mass balance for eight glaciers in the North Cascades. The average balance of these temperate glaciers was $-39 \mathrm{~cm}$ over a 10 year period (1984-94), and there was a strong correlation between time series of annual balance for the different glaciers. The regional average and glacier-to-glacier variations in mass balance observed by Pelto were similar in magnitude to those we found in the northeast Brooks Range and, because of this, we might expect a similar degree of correlation between massbalance trends of different glaciers in this part of the Brooks Range. Thus, the mass-balance trends that we have found on McCall Glacier may well represent regional trends.

\section{Mass balance and changes in terminus position}

While the long-term mass balances of our different study glaciers are for the most part similar, the corresponding rates of terminus retreat are not. In Figure 9, we show the relative change in length of each glacier. There is no consistent picture, except that each glacier has retreated. For instance, compare McCall Glacier with Gooseneck and East Okpilak Glaciers. The elevation-change curves and the average mass balances over the respective time periods are nearly identical (Table 4; Figs 7and 8), yet over the same time periods McCall Glacier retreated substantially, while Gooseneck Glacier showed negligible retreat and East Okpilak Glacier showed four times more retreat than McCall Glacier (Fig. 9). This is probably due to the particular geometry of each glacier, especially that near the terminus (e.g. Gooseneck Glacier had a vertical terminal ice face in 1956 that thinned without retreat to produce the gentle ice slope existing at present). It is clear from the results of this section that retreat of the termini of different glaciers is a complex function of glacier geometry and mass balance, a finding similar to that of Echelmeyer and others (1996) and Sapiano and others (1998) for different locations. Lichenometric dating of late Holocene moraines by Calkin and Evison (1996) also indicates a complicated pattern of terminus changes since the end of the Little Ice Age (about AD 1890) in this region of the Brooks Range.

\section{THE MASS BALANCE OF MCGALL GLACIER AND CLIMATIC CHANGE IN THE ARCTIC}

In this section we investigate the correlation between the mass balance of McCall Glacier and climatological data from weather stations $100-650 \mathrm{~km}$ away from the glacier. These correlations are used to determine how representative the balance of McCall Glacier is for this part of the Arctic on a larger ("synoptic") scale. We utilize an empirical degree-day model for the mass balance, with the massbalance data from the 1970s and 1990s and a combination of daily and monthly weather-station data. Using this model to fill gaps in balance record then allows us to speculate on the climatic causes of the increasing negative balance trend and glacier thinning.

The locations of the weather stations considered in this study are shown in Figure 1 (inset) and relevant parameters are given in Table 5. We focus on the summer temperatures at these stations, which are possibly related to ablation, and precipitation during the months in which accumulation on the glacier is likely.

\section{Model description}

Physical mass-balance models use meteorological input

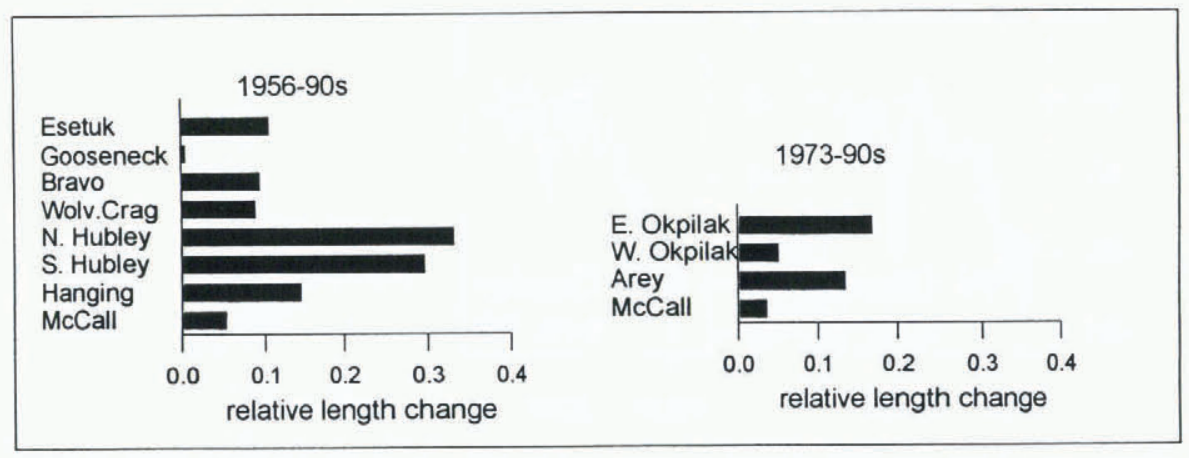

Fig. 9. Regional patterns of changes in glacier length (relative to length) for northeast Brooks Range glaciers from 1956 to the 1990 s and 1973 to the 1990 s. 
Table 5. First-order weather stations within $700 \mathrm{~km}$ radius of McCall Glacier

\begin{tabular}{|c|c|c|c|}
\hline $\begin{array}{l}\text { Weather } \\
\text { station }\end{array}$ & $\begin{array}{l}\text { Record } \\
\text { length }\end{array}$ & $\begin{array}{c}\text { Distance from } \\
\text { McCall Glacier } \\
\text { km }\end{array}$ & Local climatic setting \\
\hline Inuvik & 1961-present & 430 & $50 \mathrm{~km}$ inland, Arctic slope \\
\hline Barrow & 1948-present & 550 & Arctic coastal \\
\hline Kaktovik & $1948-1988$ & 100 & Arctic coastal \\
\hline Fairbanks & 1948 present & 650 & Continental, interior AK \\
\hline
\end{tabular}

data to predict the energy and mass fluxes at the surface of a glacier, from which the mass balance is derived. These models require high-resolution energy-balance measurements and have generally been developed for temperate glaciers (e.g. Oerlemans, 1992; Conway and others, 1995), and they do not account for internal accumulation. For these reasons, we use an empirical mass-balance model, essentially a least-squares regression of the measured massbalance series with two climatological inputs. The first is the sum of positive degree days, $D$, as calculated from twice-daily radiosonde soundings made at one of the weather stations listed in Table 5. D is calculated for the median elevation of the glacier, about $2000 \mathrm{~m}$. The second input is accumulation, $A$, as calculated from precipitation measured at one of the stations. The balance model is then simply the linear combination

$$
\Delta b=c_{\mathrm{d}} \Delta D+c_{\mathrm{a}} \Delta A
$$

where $\Delta$ marks per-cent deviations of quantities from their corresponding means during the calibration period. (If, instead, $b$ is modeled as a function of $D$ and $A$, rather than of their deviations $(\Delta)$, then a third constant appears on the righthand side. This constant can be expressed as a function of the mean values of $b, A$ and $D$.) The constants $c_{\mathrm{d}}$ and $c_{\mathrm{a}}$ are determined by the least-squares fit of Equation (1) to the set of eight measured mass balances given in Table 2. Models for both the surface and the net balances (maximum internal accumulation) are presented.

Specification of the actual input parameters requires some care. Surface temperature is often influenced by local effects, such as selective heating and low stratus clouds, especially in Arctic coastal locations. For this reason, we follow Sampson (1965) and Conway and others (1995) in using the air temperature over a weather station at the median elevation of McCall Glacier, which generally falls between the 850 and the 700 mbar pressure levels. We have found that the mean layer temperature, $\bar{T}$, as determined from the hypsometric equation (List, 1963)

$$
\bar{T}=\frac{\left(z_{850}-z_{700}\right)}{67.442 \times \log \left(\frac{850}{700}\right)}-273.16
$$

shows a better correlation with measured temperatures on the glacier than does a simple interpolation of radiosonde temperatures. In this equation, $z_{850}$ and $z_{700}$ are the 850 and 700 mbar pressure levels. The daily temperature at this median elevation, $T_{\mathrm{d}}$, was calculated as the average of the two layer temperatures available each day. A comparison of $T_{\mathrm{d}}$ for each of the weather stations with the daily temperature measured at $2100 \mathrm{~m}$ on McCall Glacier (on the moraine) for May-September 1994 is shown in Figure 10a; other years show similar correlations. The daily temperature above Inuvik follows that on McCall Glacier most closely, with a correlation coefficient of $r^{2}=0.78$ for the entire period and $r^{2}=0.66$ if only positive temperatures are considered (Fig. 10b). These correlations are quite good, especially considering the distance to the station. A high degree of correlation also suggests that temperatures on the moraine at McCall Glacier are not affected by local heating. Correlations for Barrow and Fairbanks are not as strong $\left(r^{2}=0.54\right.$ and 0.51 for the entire period, respectively). Correlation coefficients of similar magnitude were found by Conway and others (1995) between temperatures on Blue Glacier (Washington) and those at a nearby radiosonde station, although that station was much closer to the glacier $(70 \mathrm{~km})$.

The sum of positive degree days in a given year is obtained from these daily temperatures as

$$
D=\sum_{\text {bal.year }} \max \left[T_{\mathrm{d}}, 0^{\circ} \mathrm{C}\right] \text {. }
$$

This sum was calculated for all years on record for each of the stations.

As a measure of precipitation on the glacier, we tried the daily precipitation at Inuvik and Barrow. No acceptable correlation was found with the 1994 measurements on the glacier. Because of this, we chose to calculate the annual accumulation on the glacier, $A$, from the monthly precipitation, $P_{\mathrm{m}}$, at Inuvik or Barrow. This was done in two ways in order to bracket the amount of internal accumulation. First, we summed the "solid" precipitation over lyear, beginning with month $m_{1}$ in autumn of the previous year. The amount of solid precipitation was estimated using the fraction of days, $N_{\mathrm{m}}\left(T_{\mathrm{d}}<0^{\circ} \mathrm{C}\right) / N_{\mathrm{m}}$ during the month in which the daily temperature, $T_{\mathrm{d}}$, was below freezing. Here, $N_{\mathrm{m}}$ is the number of days in month $m$. Thus,

$$
A=\sum_{m_{1}}^{m_{1}+1 \text { year }} P_{\mathrm{m}} \frac{N_{\mathrm{m}}\left(T_{\mathrm{d}}<0^{\circ} \mathrm{C}\right)}{N_{\mathrm{m}}} .
$$

The remainder of the total precipitation is assumed to be lost as run-off. While this is reasonable for accumulation on temperate glaciers and for surface accumulation in general, net accumulation on Arctic glaciers may be greater as a result of internal accumulation. To allow for this in the mass-balance model, we also used a second, alternative expression for $A$

$$
A=\sum_{m_{1}}^{m_{2}} P_{\mathrm{m}} .
$$

In this case, all of the monthly precipitation falling between month $m_{1}$ in the previous autumn and month $m_{2}$ of the actual balance year is assumed to contribute to the net accumulation. Neither Equation (4) or (5) accounts for the part of internal accumulation that is due to refreezing of surface melt; this latter part depends on summer temperature defined in Equation (3).

\section{Results of the mass-balance model}

As stated earlier, both the surface balances and the net balances in Table 2 were used (independently) to calibrate the model. There were two main sets of criteria used to judge the quality of the fit: first, the correlation coefficients between measured mass balance and degree days and accumulation, and secondly, an examination of how well the long-term average annual net balances for the periods $1958-72(-15 \mathrm{~cm})$ and $1972-93(-33 \mathrm{~cm})$ were reproduced. 

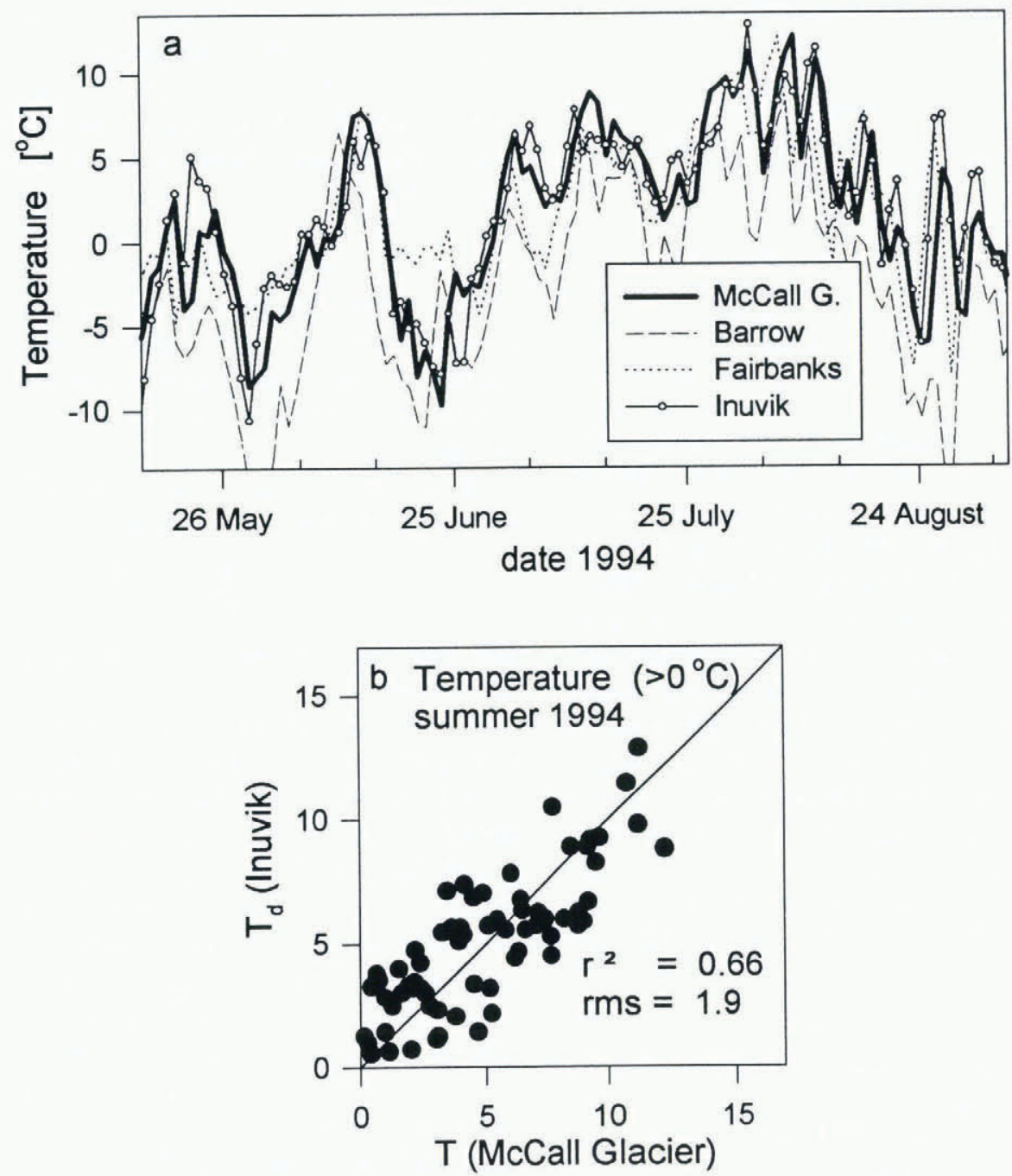

Fig. 10. (a) Average daily temperatures measured on McCall Glacier at $2100 \mathrm{~m}$ during summer 1994 compared to the mean temperature of the 700 850 mbar layer over Inuvik, Barrow and Fairbanks. (b) Correlation between the temperatures on McCall Glacier and $T_{\mathrm{d}}$ from Inuvik soundings during summer 1994. Only positive temperatures, which enter the positive degree-day sum, are shown.

Additional criteria were used to constrain the solutions, including the physically reasonable assumption that an increase in precipitation at a station should cause a more positive mass balance on the glacier, not more negative.

In order to find the best choices of stations, months of precipitation, and relation between station precipitation and accumulation (Equations (4) or (5)), numerous calibration model runs were conducted. Here, we present only the salient features of these runs, focusing on those which gave the best fits to the data. Parameters for two typical surface balance models using data from Barrow are presented in Table 6, and for Inuvik in Table 7a. In Table 7b, we present similar results for the best net balance models using Inuvik data. The first columns list the equation used to calculate accumulation from $P_{\mathrm{m}}$ and the limiting months in Equations (4) or (5), the next four are the multi-variable $\left(C_{\text {multi }}\right)$,

Table 6. Results of mass-balance model with Barrow data

Using measured annual surface balances

\begin{tabular}{|c|c|c|c|c|c|c|c|c|c|c|}
\hline $\begin{array}{l}\text { Accumulation } \\
\text { model }\end{array}$ & $m_{1}$ & $m_{2}$ & $C_{\text {multi }}$ & $C_{\mathrm{A}}$ & $C_{\mathrm{D}}$ & $C_{\mathrm{DA}}$ & $\begin{array}{c}\langle b\rangle \\
58-72 \\
\mathrm{~cm}\end{array}$ & $\begin{array}{c}\langle b\rangle \\
72-93 \\
\mathrm{~cm}\end{array}$ & $c_{\mathrm{a}}$ & $c_{\mathrm{d}}$ \\
\hline Equation (4) & 8 & - & 0.98 & -0.88 & -0.23 & -0.22 & -115 & -78 & -1.53 & -0.36 \\
\hline Equation (5) & 8 & 6 & 0.99 & -0.93 & -0.23 & -0.14 & -96 & -77 & -1.30 & -0.29 \\
\hline
\end{tabular}

$\begin{array}{ll}\text { Key: } & \text { Start/ending months in Equations (4) and (5). } \\ m_{1}, m_{2} & \text { Correlation coefficients: between mass balance and accumulation/degree days both and between } \\ & \text { accumulation and degree days. } \\ \langle b\rangle & \text { Mean mass balance over period indicated. } \\ c_{\mathrm{a}}, c_{\mathrm{d}} & \text { Model parameters: for accumulation/degree days. }\end{array}$


(a) Using measured surface balances

\begin{tabular}{|c|c|c|c|c|c|c|c|c|c|c|}
\hline $\begin{array}{l}\text { Accumulation } \\
\text { model }\end{array}$ & $m_{1}$ & $m_{2}$ & $C_{\text {multi }}$ & $C_{\mathrm{A}}$ & $C_{\mathrm{D}}$ & $C_{\mathrm{DA}}$ & $\begin{array}{c}\langle b\rangle \\
58-72 \\
\mathrm{~cm}\end{array}$ & $\begin{array}{c}\langle b\rangle \\
72-93 \\
\mathrm{~cm}\end{array}$ & $c_{\mathrm{a}}$ & $c_{\mathrm{d}}$ \\
\hline $\begin{array}{l}\text { Equation (4) } \\
\text { Equation (5) }\end{array}$ & $\begin{array}{l}8 \\
8\end{array}$ & - & $\begin{array}{l}0.95 \\
0.96\end{array}$ & $\begin{array}{l}0.42 \\
0.30\end{array}$ & $\begin{array}{l}-0.82 \\
-0.82\end{array}$ & $\begin{array}{l}0.06 \\
0.22\end{array}$ & $\begin{array}{l}29.6 \\
-31.1\end{array}$ & $\begin{array}{l}-45.1 \\
-45.8\end{array}$ & $\begin{array}{l}0.68 \\
0.68\end{array}$ & $\begin{array}{l}-0.82 \\
-0.90\end{array}$ \\
\hline $\begin{array}{l}\text { Equation (4) } \\
\text { Equation (5) }\end{array}$ & $\begin{array}{l}8 \\
8\end{array}$ & $\frac{-}{6}$ & $\begin{array}{l}0.96 \\
0.98\end{array}$ & $\begin{array}{l}0.49 \\
0.37\end{array}$ & $\begin{array}{l}-0.80 \\
-0.80\end{array}$ & $\begin{array}{l}0.06 \\
0.22\end{array}$ & $\begin{array}{l}-18.1 \\
-19.4\end{array}$ & $\begin{array}{l}-31.5 \\
-32.1\end{array}$ & $\begin{array}{l}0.62 \\
0.62\end{array}$ & $\begin{array}{l}-0.66 \\
-0.73\end{array}$ \\
\hline
\end{tabular}

Key: same as Table 6.

single variable $\left(C_{\mathrm{D}}\right.$ for $D$ and $C_{\mathrm{A}}$ for accumulation), and cross-correlation $\left(C_{\mathrm{DA}}\right)$ coefficients (as defined by e.g. Letréguilly, 1988), the next two are the long-term annual balances calculated from the model (for Inuvik, the station record does not completely overlap the 1958-72 time period), and the last two columns are the coefficients $c_{\mathrm{d}}$ and $c_{\mathrm{a}}$ in the resulting model (Equation (1)).
Surface mass-balance predictions for the best-fit model over the entire span of the station data are shown in Figure lla for Barrow, and in Figure 12a for Inuvik. The models shown are those for which Equation (5) is used to define the $D$ to $A$ relationship, with parameters given in the first row in Table 6 and $7 \mathrm{a}$. The shaded band in these figures is the error in the solution obtained by assuming variations of
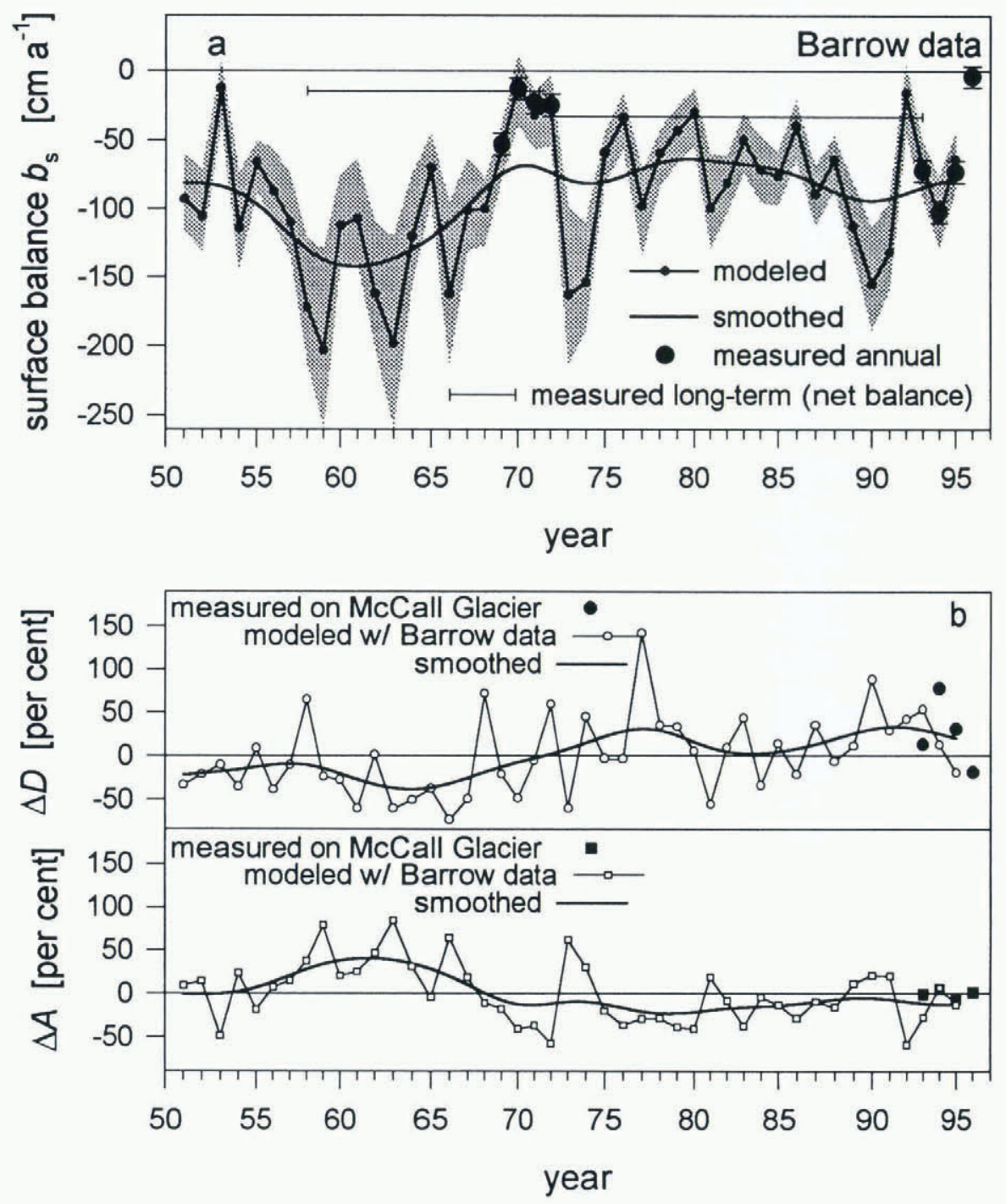

Fig. 11. Barrow data: (a) Modeled, Equation (4) and $m_{1}=8$, and measured surface mass balance of McCall Glacier. Measured long-lerm balance is given for comparison. (b) Per-cent deviations from 1951-9.5 mean of annual degree-day sum D and solid precipitation A. Modeled values are represented by open symbols connected with solid lines, while those measured on McCall Glacier are represented by solid symbols. 

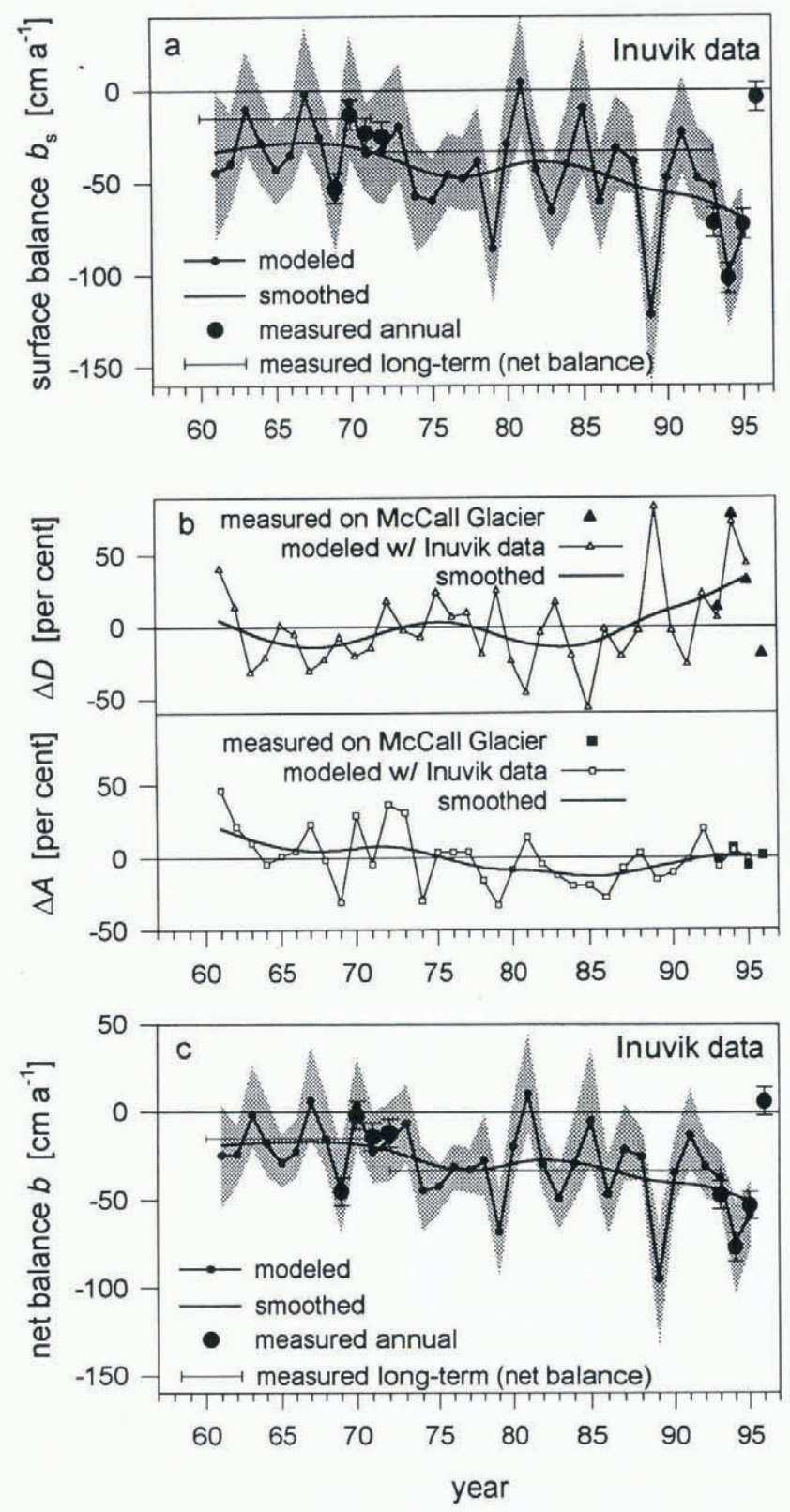

Fig. 12. Inuvik data: (a) Modeled surface balance, using Equation (4) and $m_{1}=8$, and measured annual surface mass balances of McCall Glacier. Measured long-term balance is given for comparison. (b) Per-cent deviations from 1961-95 mean of annual degree day sum $D$ and solid precipitation A. Modeled values are represented by open symbols connected with solid lines, while those measured on McCall Glacier are represented by solid symbols. (c) Modeled net balance, using Equation (4), $m_{1}=8$, and measured annual and long-term net balances of McCall Glacier.

$15 \%$ in $D$ and $A$, and an error of $\pm 8 \mathrm{~cm}$ in the measured balances (shown as solid circles). A smoothed curve through the modeled balances is shown as a light line in each figure; and this curve illuminates any trends. The input data for each model are shown in Figures $11 \mathrm{~b}$ and $12 \mathrm{~b}$, respectively. Figure 12c shows the modeled net balance using the Inuvik data and Equation (4) (the first row in Table 7b).

We describe results from each of the model runs in turn:

(1) Barrow. At a first glance, some of the correlations using the Barrow data seem to be significant. However, the degree-day correlation coefficients are small $\left(C_{\mathrm{D}}<0.28\right)$, implying that the balance is not strongly correlated with temperature. This is unexpected for McCall Glacier.
More importantly, there is a negative correlation between surface balance and accumulation - not a physically realistic prediction. In addition, the modeled long-term average net balances of $-89 \mathrm{~cm}$ for 1958-72 and $-57 \mathrm{~cm}$ for the $1972-93$ period are much more negative than the measured values $(-15$ and $-33 \mathrm{~cm}$, respectively). Also, the long-term trends in balance do not agree with those in the degree day sums (cf. Fig. 1la and b). Thus, we conclude that there is no significant and realistic correlation between Barrow climatological data and the mass balance of McCall Glacier.

(2) Inuvik. The correlations of Inuvik data with the balance on McCall Glacier are generally good, especially when the most reasonable months are used as starting and ending dates in Equations (4) and (5). Based on the sonic-ranger data and our observations in the field, accumulation for the balance year begins in mid-August and ends in June. Thus, we would expect that $m_{1}=8$ in Equation (4), and $m_{1}=8$ and $m_{2}=6$ in Equation (5). Models with these values of $m_{1}$ and $m_{2}$ give the best fits to the measured balances, although a variation of \pm 0.5 month in these parameters does not change the correlation a great deal. There is a strong negative correlation between balance and Inuvik degree days $\left(C_{\mathrm{D}}=-0.8\right)$, and a somewhat weaker, but positive (and, therefore, physically meaningful) correlation with Inuvik precipitation $\left(C_{\mathrm{A}}=0.3-0.4\right)$. If the net balances in Table 2 are used to calibrate the model, then the modeled long-term average net balances are $-18 \pm 4 \mathrm{~cm}$ and $-32 \pm 3 \mathrm{~cm}$ for $1961-72$ and $1972-93$, respectively. This is in excellent agreement with measured long-term net balances. The trends in balance and the estimated degree-day sums also agree well with the measured values, as shown in Figure $12 \mathrm{a}-\mathrm{c}$. We conclude that the climatological variables at Inuvik are significantly correlated with the balance on McCall Glacier, and that they can be used to model the balance as a function of time. Equations (4) and (5) gave similar results for the model parameters and correlation coefficients and, thus, they both appear to be useful in defining the precipitation-accumulation relationship.

The correlation coefficients between the McCall Glacier mass balance and climatological parameters from Inuvik are similar to what Pelto (1996) found in his study of eight North Cascade (Washington) glaciers. He found that correlation coefficients between balance and ablation-season temperature were between 0.68 and 0.84 , while the correlation with accumulationseason temperature (a measure of winter precipitation for those glaciers) was between 0.35 and 0.59 .

(3) Kaktovik. Unfortunately, the climatological record at Kaktovik, $100 \mathrm{~km}$ to the north ends in 1988 , so we can only use four of the measured balances in Table 2 to calibrate a model using these data. In order to determine whether such a limited calibration is meaningful, we first attempted it using the 1969-72 sub-set with the Inuvik data, which, as has been shown above, gave good results with the full balance set. The calibration with the Inuvik sub-set showed a consistently good correlation using Equation (5) and the long-term balances were also in good agreement with those listed in Table 7a, implying that the reduced calibration set can produce meaningful results. 
Applying this limited calibration method to the Kaktovik data, we obtain $+15 \mathrm{~cm}$ for the average annual surface balance from 1958 to 1972 and $-35 \mathrm{~cm}$ for 1972 88. These results for Kaktovik show the correct qualitative trend towards more negative balances but they are otherwise quite different from the corresponding measured values and from the Inuvik model results. We also compared the annual balances from 1961 to 1988 predicted by the Inuvik model and those using Kaktovik data. The correlation between the two was poor. We conclude that despite its closer proximity, Kaktovik is considerably less suitable than Inuvik for modeling the mass balance of McCall Glacier. Reasons for this are given below.

(4) Fairbanks. Replacing the degree-day sum in the Inuvik model with the sum for Fairbanks causes a general drop in correlation and increases the misfit between measured and modeled long-term mass balances. However, the correlations and the modeled long-term values are superior to those from Barrow or Kaktovik. This implies that, while climate change in interior Alaska is clearly different from that at McCall Glacier, these differences are less pronounced than those between McCall Glacier and the two Arctic coastal locations.

\section{Discussion}

The excellent correlation of the McCall Glacier mass balance with climatological parameters from Inuvik, $430 \mathrm{~km}$ to the east, suggests this glacier can provide a climatic index for this part of the Arctic. The trend over the last four decades towards increasingly negative balance is likely caused by a synoptic scale $(\sim 500-1000 \mathrm{~km})$ climate change.

It is interesting to compare this synoptic-scale representivity with that over a larger scale $(\geq 1500 \mathrm{~km})$ across the Arctic. Mass-balance records from other high northern latitude glaciers (summarized by Cogley and others (1995, 1996)) do not confirm an Arctic-wide trend in the climate. In fact, the 35 year long mass-balance record of White Glacier, the main focus of Cogley and others' study, shows no significant trend. The White Glacier record, measured about $1500 \mathrm{~km}$ to the northeast of Inuvik, shows no correlation with climatological parameters from Inuvik nor with the balance of McCall Glacier. The difference in trends between McCall and White Glaciers is further illustrated by a comparison of their long-term balances, calculated for White Glacier from data presented by Cogley and others (1995): from 1958 to 1972, the average balance on McCall Glacier was $-15 \mathrm{~cm}$ and on White Glacier (from 1960 to 1972) it was $-12 \pm 4 \mathrm{~cm}$. From 1972 to 1993 , it was $-33 \mathrm{~cm}$ on McCall Glacier, while on White Glacier it was much less negative $(-10 \pm 3 \mathrm{~cm})$ from 1972 to 1991 .

The poor correlation between the McCall Glacier mass balance and climatological parameters from Barrow and Kaktovik implies that climate-change patterns have been different at these Arctic locations. To reveal these different patterns, in Figure 13 we compare smoothed time series of $D$ and $A$ for the different stations and up to 45 years duration. The positive degree-day sum (Fig. 13a) shows a regular pattern of maxima and minima, superimposed on a linear warming trend. The period of the oscillations is not well-resolved but it was estimated to be about 18-20 years for Barrow and Kaktovik, and about 16 years for Fairbanks and
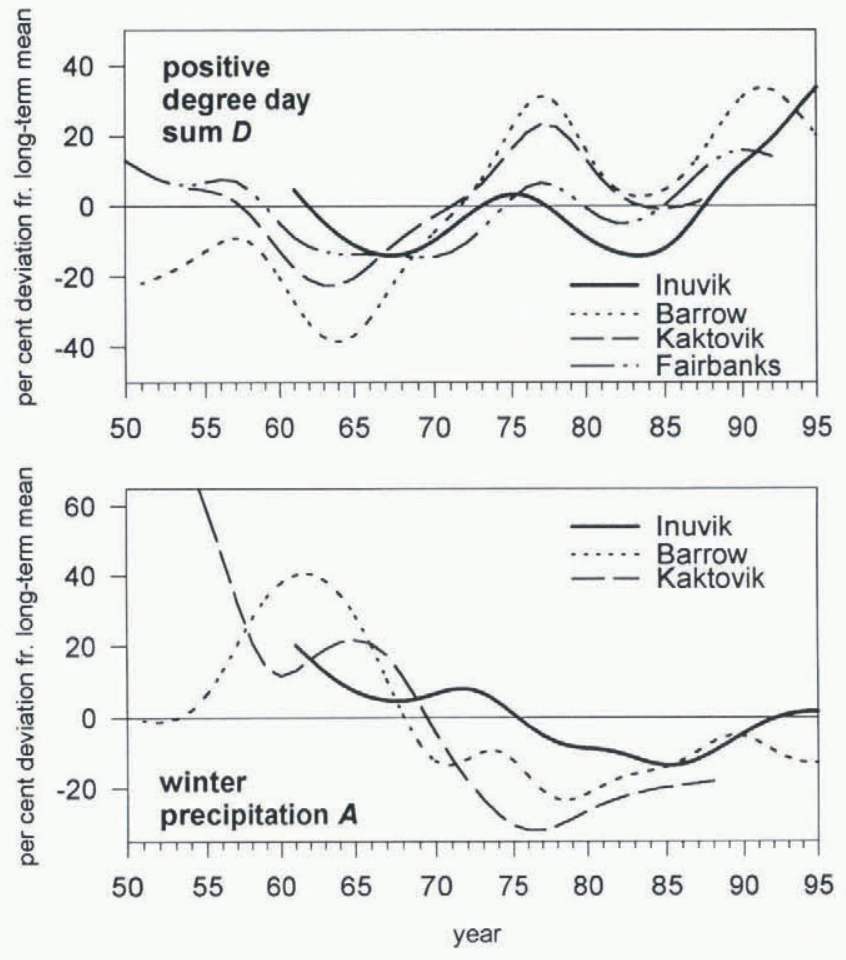

Fig. 13. Smoothed (Gauss filter of width 2.5 a) annual degree day sum at 2100 m elevation (a) and solid precipitation (b) as calculated from Inuvik, Barrow, Kaktovik and Fairbanks data.

Inuvik. Accumulation (Fig. 13b) shows an overall trend toward smaller values with a less well-defined cyclic pattern. There was an anti-correlation between winter precipitation and summer temperature at Barrow and Kaktovik. Such an anti-correlation has also been observed between the mean annual temperature and winter precipitation at these two stations (Zhang and Osterkamp, 1993) but it is contrary to the generally accepted idea of a coupled increase in temperature and precipitation in the Arctic (e.g. Houghton and others, 1996). Inuvik shows smaller oscillations in $A$ that are more in phase with those in $D$, further illustrating the difference between the climate at McCall Glacier and Inuvik and that at Barrow and Kaktovik.

It is interesting that the McCall Glacier mass balance and the climatological variables at Kaktovik, only $100 \mathrm{~km}$ away, are poorly correlated, while conditions at locations that are several hundred kilometers apart from another (such as McCall Glacier and Inuvik, and Barrow and Kaktovik) are well correlated with one another. We propose that these correlations are related to the mean summer position of the Arctic Front. Barry (1967) has compiled the statistics on the summer position of the Arctic Front over North America for a 5 year period. He found that the mean summer temperature of an Arctic region is related to its mean frontal position. In particular, the front always lies to the south of White Glacier in the Canadian Arctic and that glacier is therefore truly Arctic in regime. Barrow and Kaktovik were both north of the mean frontal positions for all 5 years, while the front was north of Inuvik and McCall Glacier about $65 \%$ of the summers.

Changes in climate may be related to corresponding displacements in the mean summer position of the Arctic Front. This would synchronously affect regions located along the length of the front in an east-west direction for possibly several hundred kilometers, and possibly cause 
similar climatic changes parallel to it (such as Inuvik and McCall Glacier or Barrow and Kaktovik). Locations separated in a north-south direction, normal to the front, may experience differing climate changes, even if they are relatively close together (e.g. McCall Glacier and Kaktovik). Further evidence for the importance of the Arctic Front has been given by Scott (1992), who showed that mean summer temperatures at tree line in Canada are significantly correlated with the magnitude of the characteristic change in air temperature that marks the passage of the front in spring.

Other factors may also cause the climate of the coastal stations to differ from those located some distance inland (McCall Glacier and Inuvik), such as summer sea-ice conditions. However, our calculations of degree days involve temperatures measured $1000+\mathrm{m}$ above the ground and, therefore, local phenomena such as coastal fog cannot be directly linked to differences in $D$.

\section{CONGLUSIONS}

We have determined an internally consistent mass-balance record for McCall Glacier for the years 1969-72 and 199396. The 1970 s data were re-evaluated under the same framework as the 1990s data. Separate records of surface mass balance and net balance, which include internal accumulation, were compiled. Average surface balance was $-29 \pm 3 \mathrm{~cm}$ from 1969 to 1972 , and $-63 \pm 3 \mathrm{~cm}$ during the period 1993-96. The corresponding annual net balances were about -19 and $-43 \mathrm{~cm}$, respectively. This pronounced trend towards negative mass balances is confirmed by longterm average net balances, which were determined from topographical volume changes: $-15 \mathrm{~cm}$ from 1958 to 1972 , and $-33 \mathrm{~cm}$ from 1972 to 1993 . The gradient of the surface mass balance with elevation increased by $17 \%$ between the periods 1969-72 and 1993-96.

Net mass balance is consistently about $25-30 \%$ more positive than the surface balance on McCall Glacier, a result of internal accumulation in the cold firn and ice. In the years $1969-72$, about $50 \%$ of the net accumulation was internal, while during the period 1993-96 almost all of it was internal. A direct comparison of the average surface balance from 1993 to 1994 with the corresponding net balance determined by repeat surveys of glacier-surface elevation gave an average internal accumulation of $+22 \pm 13 \mathrm{~cm} \mathrm{a}^{-1}$ for this 2 year period, which again was most of the net accumulation.

Long-term average net balances over the periods 1956-93 and 1972-93 for McCall Glacier and ten other glaciers in the northeast Brooks Range were determined by comparison of 1956 and 1973 photogrammetric maps with surface-elevation profiles made in the $1990 \mathrm{~s}$. The glaciers revealed a broadly similar pattern of negative annual mass balances, most of which (including McCall Glacier) were about $-30 \mathrm{~cm}$. A few of the glaciers showed somewhat more negative mass balances of about $-50 \mathrm{~cm}$. The amount of thinning, as a function of elevation on McCall Glacier, was also roughly similar to that observed on the other glaciers. This implies that the mass balance of McCall Glacier is representative of the glaciers in this region.

Mean retreat rates and fractional length changes were also measured for these 11 glaciers. They show a more complicated regional pattern than the mass balances, with some glaciers showing a concomitant retreat with the ongoing thinning, and others showing little retreat under similar thinning. The differences in retreat rate and fractional length change are probably caused by differences in glacier geometry, especially near the termini.

The measured mass-balance record of McCall Glacier shows a significant correlation with climatological parameters from Inuvik, $430 \mathrm{~km}$ to the east. A mass-balance model, based on this correlation, indicates that the trend toward more negative balances is due primarily to an increase in summer temperatures, and secondarily to a simultaneous reduction in precipitation.

While there is a good correlation between McCall Glacier's mass balance and climate data from Inuvik, there is no reasonable correlation with climatological parameters from Barrow, $550 \mathrm{~km}$ to the northwest, Kaktovik, $100 \mathrm{~km}$ to the north, or from Fairbanks, $650 \mathrm{~km}$ to the south. We interpret the presence or absence of correlations between each of these stations and McCall Glacier, and between the stations themselves, as being determined by their locations relative to the mean summer position of the Arctic Front.

We conclude that the mass balance of McCall Glacier is representative on both a regional scale and a larger $(500+\mathrm{km}$, or synoptic) scale. As such, the McCall Glacier mass-balance record is an important measure of ongoing climatic change in the Arctic.

\section{ACKNOWLEDGEMENTS}

This study was supported by grant NSF-OPP-9214954 as part of the LAII program. We wish to thank G. Adalgeirsdóttir, U. Adolphs, J. DeMallie, S. Campbell, J. Sapiano, K. Swanson, D. Trabant and C. Trabant for help in the field, and to Tazlina for providing an especially entertaining field season in 1994. Special thanks are given to D. Trabant and C. Benson for access to their data and for stimulating conversations, and to W. Harrison, M. Sturm and two anonymous reviewers for their helpful comments. We are also grateful to the refuge manager and personnel of the Arctic National Wildlife Refuge for providing valuable assistance.

\section{REFERENCES}

Alley, R. B. 1995. Resolved: the Arctic controls global climate change. In Smith, W. O. and J. M. Grebmeier, eds. Arctic oceanography: marginal ice zones and continental shelves. Washington, DC, American Geophysical Union, 263-283. (Coastal and Estuarine Series 49.

American Geographical Society. 1960. Nine glacier maps, northwestern North America. New York, American Geographical Society. (AGS Special Publication 34.)

Barry, R. G. 1967. Seasonal location of the Arctic front over North America Geogr. Bull., 9 (2), 79-95.

Bowling, S. A. 1991. Problems with the use of climatological data to detect climatic change at high latitudes. In Weller, G., C. L. Wilson and B. A. B. Severin, eds. International Conference on the Role of the Polar Regions in Global Change: proceedings of a conference held June 11-15, 1990 at the University of Alaska Fairbanks. Vol. I. Fairbanks, AK, University of Alaska. Geophysical Institute/Center for Global Change and Arctic System Research, 206-209.

Calkin, P. E. and L. H. Evison. 1996. Holocene glaciation and twentieth-century retreat, northeastern Brooks Range, Alaska. Holocene, 6 (1), 17-24.

Cogley, J. G., W. P. Adams, M. A. Ecclestone, F. Jung-Rothenhäusler and C. S. L. Ommanney. 1995. Mass balance of Axel Heiberg Island glaciers, 1960 1991: a reassessment and discussion. Saskatoon. Sask., Environment Canada. National Hydrology Research Institute. (NHRI Science Report 6.)

Cogley, J. G., W. P. Adams, M. A. Ecclestone, F. Jung-Rothenhäusler and C. S. L. Ommanney. 1996. Mass balance of White Glacier, Axel Heiberg Island, N.W.T., Canada, 1960-1991. J. Glaciol., 42(142), 548-563.

Conway, H., L. A. Rasmussen and P. Hayes. 1995. On the use of radiosondes to model glacier ablation. Ann. Glaciol., 21, 245-250. 
Dorrer, E. 1975. Contribution to a general stereoscopic block analytical aerotriangulation. Dtsch. Geod. Komm., Reihe B 214, 125-136.

Dorrer, E. and G. Wendler. 1976. Climatological and photogrammetric speculations on mass-balance changes of McCall Glacier, Brooks Range, Alaska. J. Glaciol., 17 (77), 479-490.

Dowdeswell, J. A. 1995. Glaciers in the High Arctic and recent environmental change. Philos. Trans. R. Soc. London, Ser. A, 352 (1699), 321-334.

Echelmeyer, K. A. and 8 others. 1996. Airborne surface profiling of glaciers: a case-study in Alaska. J. Glaciol., 42 (142), 538-547.

Finsterwalder, R. 1954. Photogrammetry and glacier research with special reference to glacier retreat in the eastern Alps. F. Glaciol., 2 (15), 306-315.

Haakensen, N. 1986. Glacier mapping to confirm results from mass-balance measurements. Ann. Glaciol., 8, 73-77.

Houghton, J.T., L. G. M. Filho, B. A. Callander, N. Harris, A. Kattenberg and K. Maskell, eds.. 1996. Climate change 1995: the science of climate change. Cambridge, etc., Cambridge University Press.

Jóhannesson, T., C. Raymond and E. D. Waddington. 1989. Time-scale for adjustment of glaciers to changes in mass balance. f. Glaciol., 35 (121), 355-369.

Keeler, C. M. 1958. Ablation studies: Lower McCall Glacier, June 23 to September 1, 1957. IGY Glaciol. Rep. Ser., 1, XII.11-XII.15.

Kelly, P. M., P. D. Jones, C. B. Sear, B. S. G. Cherry and R. K. Tavakol. 1982 Variations in surface air temperatures: Part 2. Arctic regions, 1881-1980. Mon. Weather Rev., $110(2), 71-83$.

Krimmel, R. M. 1989. Mass balance and volume of South Cascade Glacier, Washington, 1958-1985. In Oerlemans, J., ed. Glacier fluctuations and climatic change. Dordrecht, etc., Kluwer Academic Publishers, 193206.

Lachenbruch, A. H. 1994. Permafrost, the active layer, and changing climate. U.S. Geol. Surv. Open File Rep. 94694.

Letréguilly, A. 1988. Relation between the mass balance of western Canadian mountain glaciers and meteorological data. 7. Glaciol., 34 (116), 11-18.

List, R. J. 1963. Smithsonian meleorological lables. Sixth edition. Washington, DC, Smithsonian Institute Press.

Lliboutry, L. 1974. Multivariate statistical analysis of glacier annual balances. F. Glaciol., 13 (69), 371-392.

Oerlemans, J. 1992. Climate sensitivity of glaciers in southern Norway: application of an energy-balance model to Nigardsbreen, Hellstugubreen and Alfotbreen. J. Glaciol., 38(129), 223-232.

Oerlemans, J. and J. P. F. Fortuin. 1992. Sensitivity of glaciers and small ice caps to greenhouse warming. Science, 258(5079), 115-117.

Oerlemans, J. and N. C. Hoogendoorn. 1989. Mass-balance gradients and climatic change. J. Glaciol., 35 121), 399-405.

Ostrem, G. and M. Brugman. 1991. Glacier mass-balance measurements. A manual for field and office work. Saskatoon, Sask., Environment Canada. National Hydrology Research Institute. (NHRI Science Report 4. )

Orvig, S. and R.W. Mason. 1963. Ice temperatures and heat flux: McCall Glacier, Alaska. International Association of Scientific Hydrology Publication 61 General Assembly of Berkeley 1963 - Snow and Ice), 181-188.

Osterkamp, T. E. and V. E. Romanovsky. 1996. Characteristics of changing permafrost temperatures in the Alaskan Arctic, U.S.A. Arct. Alp. Res. $28(3), 267-273$.
Pelto, M. S. 1996. Annual net balance of North Cascade glaciers, 1984 - 94. J. Glaciol., 42 (140), 39.

Pfeffer, W. T., T. H. Illangasekare and M. F. Meier. 1990. Analysis and modeling of melt-water refreezing in dry snow. F. Glaciol., 36 123), 238-246.

Rabus, B. T. and K. A. Echelmeyer. 1997. The flow of a polythermal glacier: McCall Glacier, Alaska, U.S.A. F. Glaciol., 43 (145), 522-536.

Rabus, B., K. Echelmeyer, D. Trabant and C. Benson. 1995. Recent changes of McCall Glacier, Alaska. Ann. Glaciol., 21, 231- 239.

Samson, C. A. 1965. Comparison of mountain slope and radiosonde observations. Mon. Weather Rev., 95, 327-330.

Sapiano, J. J., W. D. Harrison and K. A. Echelmeyer. 1998. Elevation, volume and terminus changes of nine glaciers in North America. y. Glaciol., 44 (146), 119-135

Sater, J. E. 1959. Glacier studies of the McCall Glacier, Alaska. Arctic, 12 (2), $82-86$.

Schwitter, M. P. and C. F. Raymond. 1993. Changes in the longitudinal profiles of glaciers during advance and retreat. f. Glaciol., 39 133), 582-590.

Scott, P. A. 1992. Annual development of climatic summer in northern North America: accurate prediction of summer heat availability. Climatic Res., 2, 91-99.

Tangborn, W. V., A. G. Fountain and W. G. Sikonia. 1990. Effect of area distribution with altitude on glacier mass balance - a comparison on North and South Klawatti glaciers, Washington State, U.S.A. Ann. Glaciol., 14, $278-282$.

Trabant, D. C. and C. S. Benson. 1986. Vliianiye vnutrennego pitaniya i formirovaniya nalozhennogo l'da na balans massy lednika Makkol na Aliaske [Influence of internal accumulation and superimposed ice formation on mass balance of McCall Glacier in Alaska. Mater. Glyatsiol. Issled. 58, 40-49 (Russian); 157-165 (English).

Trabant, D. C. and L. R. Mayo. 1985. Estimation and effects of internal accumulation on five glaciers in Alaska. Ann. Glaciol., 6, 113-117.

Trabant, D. C., W. D. Harrison and C. S. Benson. 1975. Thermal regime of McCall Glacier, Brooks Range, northern Alaska. In Weller, G. and S. Bowling, eds. Climate of the Arctic. Fairbanks, AK, University of Alaska, Geophysical Institute, 347-349.

Wakahama, G., D. Kuroiwa, T. Hasemi and C. S. Benson. 1976. Field observations and experimental and theoretical studies on the superimposed ice of Mc Call Glacier, Alaska. J. Glaciol., 16 (74), 135-149.

Wendler, G. and N. Ishikawa. 1974. The effect of slope, exposure and mountain screening on the solar radiation of McCall Glacier, Alaska: a contribution to the International Hydrological Decade. F. Glaciol., 13(68), $213-226$.

Wendler, G., C. Fahl and S. Corbin. 1972. Mass balance studies on the McCall Glacier, Brooks Range, Alaska. Arct. Alp. Res., 4 (3), 2Il-222.

Wendler, G., N. Ishikawa and N. Streten. 1974. The climate of the McCall Glacier, Brooks Range, Alaska in relation to its geographical setting. Arcl. Alp. Res., 6 (3),307-318.

Zhang, T. and T. E. Osterkamp. 1993. Changing climate and permafrost temperatures in the Alaskan Arctic. In Cheng, G., ed. Permafrost, Sixth International Conference Proceedings, Vol. I, July 59 1993, Beijing, China. Guangzhou, South China University of Technology Press, 783-788. 